Copyright (C) 2017 by Academic Publishing House Researcher

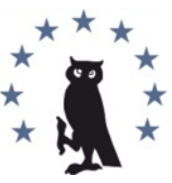

Published in the Russian Federation

European Researcher. Series A

Has been issued since 2010.

ISSN 2219-8229

E-ISSN 2224-0136

2017, 8(3): 122-153

DOI: $10.13187 /$ er.2017.3.122

www.erjournal.ru

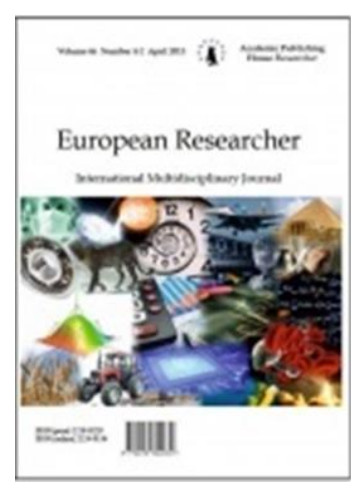

UDC 378

\title{
Quantitative and Genre Dynamics of Film Production of Soviet and Russian Films related to the Subject of the School and University
}

\author{
Alexander Fedorov ${ }^{a, *}$

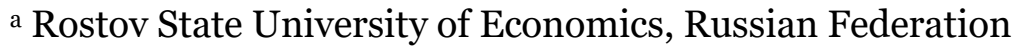

\section{Abstract}

The so-called stagnation period (1969-1985) is the peak of interest in the school / university topic on the Soviet/Russian screen: 127 films (36.4 \% of the total number of films on this topic) appeared on the country's screens. The second place is the Russian period (1992-2017) - 93 films (26.7 \%). A notable drop in the number of films about the school and university was noted in the 1990 , and this was due to a general decrease in film production in Russia. The period from 1919 to 2017 has the specific genre situation in the school / university film topic: drama - 220 (63.0 \%), comedy - 82 (23.5\%), melodrama - 36 (10.3\%).

The dramatic genre was especially prevalent (about $90 \%$ of all films about the school and university) between 1919 and 1955 and during the "perestroika" period, while the peaks of the production of comedies fell on the Russian period: $41 \%$ of all films on the school and university theme and the period "stagnation", when this type of tape accounted for a fourth. Dominant of the drama is quite understandable: not only school and college subjects, but the cinema as a whole was primarily focused on the dramatic genre in the Soviet time. Comedies and melodramas grew more in the years of relative social stability, while dramatic stories dominated the years when confrontation prevailed in society.

Keywords: film, USSR, Russia, school topic, school, students, pupils, teacher, cinematography, cinema.

\section{1. Введение}

Изучение научных трудов выявляет противоречие между относительно подробной разработанностью аспектов школьной и вузовской тематики в игровых фильмах (Аркус, 2010; Баранов, 1979; Громов, 1982; Кабо, 1974; 1978; Жарикова, 2015; Левшина, 1978; 1989; Парамонова, 1975; 1976; Пензин, 1973; 1986; Рабинович, 1969; Рыбак, 1980; Строева, 1962; Толстых, 1988; Усов, 1980; Шипулина, 2010 и др.) и недостаточным вниманием исследователей к статистической стороне данной темы.

Отметим, что труды ученых советского периода, посвященные теме школы и вуза, нередко находились под очень сильным влиянием коммунистической идеологии (это весьма характерно, например, для работ К.К. Парамоновой и Ю.М. Рабиновича), что, на наш взгляд, мешало всестороннему анализу - как культурологических, киноведческих, так и

\footnotetext{
${ }^{*}$ Corresponding author

E-mail address: 1954alex@mail.ru (A.V.Fedorov)
} 
статистических аспектов заявленной темы.

Что касается зарубежных ученых, то их в первую очередь интересовал политический анализ советских и постсоветских медиатекстов (Dubois, 2007; Kenez, 1992; Lawton, 2004; Shaw \& Youngblood, 2010; Shlapentokh, 1993; Strada, 1989; Strada \& Troper, 1997), а не анализ экранной школьно-студенческой тематики.

\section{2. Материалы и методы исследования}

Материал нашего исследования - игровые фильмы на тему школы и вуза; сравнительный анализ фильмопроизводства, касающегося данной тематики, включая анализ временных периодов и жанров.

\section{3. Обсуждение}

Исследователи (как отечественные, так и западные) до сих пор не пытались выйти на статистический аспект сравнительного анализа развития школьно-студенческой темы в зеркале аудиовизуальных медиатекстов (в кино, на ТВ, в Интернете и др.), хотя, на наш взгляд, он весьма полезен - как в социологическом, так и в культурологическом планах.

Стоит отметить, что отечественные исследователи - и в советское время, и в современный период - обращались в основном к эстетическому и идеологическому анализ игровых фильмов на тему школы и вуза, как правило, минуя киностатистику.

Что касается трудов зарубежных ученых (Dubois, 2007; Kenez, 1992; Lawton, 2004; Shaw \& Youngblood, 2010; Shlapentokh, 1993; Strada, 1989; Strada \& Troper, 1997 и др.), то они в своих трудах, касающихся советских и российских аудиовизуальных медиатекстов, не обращались к анализу школьной и вузовской темы. Во всяком случае, в ходе предварительных изысканий по теме, заявленной в нашем исследовании, нам не удалось обнаружить сколь либо существенного анализа школьной и вузовской тематики в советских и постсоветских аудиовизуальных медиа ни в одной из работ западных ученых; хотя, разумеется, они исследовали образ школы и вуза в западных аудиовизуальных медиатекстах (в основном - на материале кино) (Ayers, 1994; Bauer, 1998; Burbach, Figgins, 1993; Considine, 1985; Dalton, 1999;. Edelman, 1990; Farber, Holm, 1994; Joseph, Burnaford, 1994; Keroes, 1999; Oliker, 1993; Schwartz, 1963; Trier, 2001 и др.).

Не удалось нам найти и западных исследований, где бы затрагивался статистический аспект заявленной нами темы, хотя он представляется нам немаловажным.

\section{4. Результаты исследования}

Проследим количественную и жанровую динамику производства советских и российских фильмов, связанных с тематикой школы и вуза, с 1919 по 2017 годы (в этот период в СССР и России в целом было поставлено около 350 игровых картин на эту тему).

Для этого мы условно разделили фильмы советского периода на тему школы и вуза на следующие группы:

1) фильмы периода немого кино (1919-1930) - 12 лет;

2) фильмы звукового периода кино сталинской эпохи и первых пост-сталинских лет (1931-1955) - 25 лет;

3) фильмы периода «оттепели» (1956-1968) - 13 лет;

4) фильмы периода «стагнации» (1969-1984) - 16 лет;

5) фильмы периода «перестройки» (1985-1991) - 7 лет;

6) фильмы российского периода (1992-2017) - 26 лет.

Разумеется, временные рамки каждого из этих периодов, по-нашему мнению, не могут быть определены абсолютно точно, так как существуют различные мнения относительно длительности отдельных периодов (к примеру, периода «оттепели»).

В таблице 1 приводятся подробные цифровые данные по советским и российским фильмам, связанным с тематикой школы и вуза, по которым можно проследить пики ее востребованности в кинематографе. 
Таблица 1. Число советских и российских фильмов, связанных с тематикой школы и вуза (с 1919 по 2017 годы)

\begin{tabular}{|c|c|c|c|c|c|}
\hline \multirow{2}{*}{$\begin{array}{c}\text { Временные } \\
\text { периоды }\end{array}$} & \multicolumn{4}{|c|}{ Жанры фильмов о школе и вузе } & \multirow[b]{2}{*}{$\begin{array}{c}\text { Всего } \\
\text { фильмов }\end{array}$} \\
\hline & $\begin{array}{c}\text { Драма } \\
\text { (число и } \\
\%)\end{array}$ & $\begin{array}{c}\text { Комедия } \\
\text { (число и \%) }\end{array}$ & $\begin{array}{l}\text { Мелодрама } \\
\text { (число и \%) }\end{array}$ & $\begin{array}{c}\text { Другие } \\
\text { жанры } \\
\text { (число и \%) }\end{array}$ & \\
\hline $1919-1930$ & $9(90,0)$ & $\mathrm{O}(0,0)$ & $0(0,0)$ & $1(10 \%)$ & $10(2,8)$ \\
\hline 1931-1955 & $28(87,5)$ & $4(12,5)$ & $\mathrm{o}(0,0)$ & $\mathrm{o}(0,0)$ & $32(9,1)$ \\
\hline $1956-1968$ & $31(67,4)$ & $8(17,4)$ & $6(13,0)$ & $1(2,2)$ & $46(13,2)$ \\
\hline $1969-1985$ & $79(62,2)$ & $31(24,4)$ & $14(11,0)$ & $3(2,4)$ & $127(36,4)$ \\
\hline 1986-1991 & $37(90,3)$ & $1(2,4)$ & $1(2,4)$ & $2(4,9)$ & $41(11,8)$ \\
\hline $1992-2017$ & $36(38,7)$ & $38(40,9)$ & $15(16,1)$ & $4(4,3)$ & $93(26,7)$ \\
\hline ИТОГО: & $220(63,0)$ & $82(23,5)$ & $36(10,3)$ & $11(3,2)$ & 349 \\
\hline
\end{tabular}

Если свести данные таблицы 1 в диаграммы, то они будет выглядеть следующим образом:

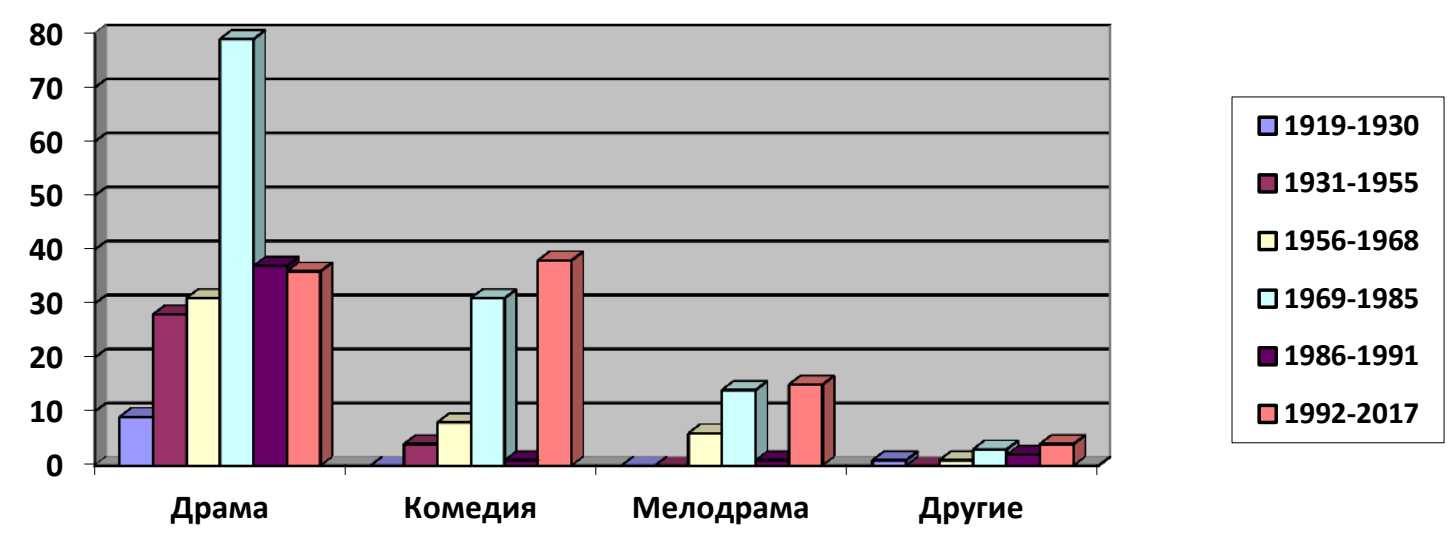

Рис. 1. Число советских и российских фильмов, связанных тематикой школы и вуза, распределенных по временным периодам и жанрам



Рис. 2. Число советских и российских фильмов, связанных тематикой школы и вуза, распределенных по временным периодам и жанрам (в процентах)

\section{5. Выводы}

Как по таблице 1, так и по рисункам 1 и 2 можно увидеть, что период пик интереса к школьной/вузовской теме на экране пришелся на так называемый период «застоя» (1969- 
1985), когда на экраны страны вышло 127 лент (36,4 \% от общего числа фильмов на эту тему). На втором месте идет российский период (1992-2017) - 93 лент (26,7 \%).

Ощутимое снижение числа фильмов о школе и вузе отмечалось в 1990-х годах, и связано это было с общим уменьшением фильмопроизводства в России.

Интересно также проследить, как изменялось соотношение числа игровых фильмов, связанных со школьной/вузовской тематикой, распределенных по жанрам. Как видно из таблицы 1 и рисунка 2, в жанровом отношении в период с 1919 по 2017 год в школьной/вузовской кинотематике доминировали: драмы - 220 (63,0\%), комедии - 82 (23,5\%), мелодрамы - 36 (10,3\%).

Данные рисунка 2 показывают, что драматический жанр особенно преобладал (около 90 \% всех фильмов о школе и вузе) в период 1919-1955 годов и во времена «перестройки», тогда как пики производства кинокомедий пришлись на российский период: 41 \% всех фильмов на школьно-вузовскую тему (при этом значительная часть фильмов о вузе - a российский период 2000-х годов ощутимо лидирует именно по части вузовской тематики решалось именно в жанре комедии) и период «застоя», когда такого рода ленты составляли четвертую часть.

Доминанта драмы вполне объяснима - в советские времена не только школьновузовские сюжеты, но кинематограф в целом был ориентирован, прежде всего, именно на драматический жанр.

Сравнение данных таблицы 1 и рисунка 2 с составленной нами фильмографией фильмов на школьно-вузовскую тему, обнаруживает, что комедий и мелодрам становилось больше именно в годы относительной общественной стабильности, в то время как драматические сюжеты доминировали в годы, когда в социуме преобладала конфронтация.

\section{6. Благодарности}

Исследование выполнено за счет финансовых средств гранта Российского научного фонда (РНФ, проект № 17-18-01001)» в Ростовском государственном экономическом университете. Тема проекта: «Школа и вуз в зеркале советских, российских и западных аудиовизуальных медиатекстов». Руководитель проекта А.В. Федоров.

\section{Литература}

Аркус, 2010 - Аркус Л. Приключения белой вороны: эволюция «школьного фильма» в советском кино // Сеанс. 2010. 2 июня. URL: http://seance.ru/blog/whitecrow/

Баранов, 1979 - Баранов О.А. Экран становится другом. М.: Просвещение, 1979. 96 с.

Григорьева, 2007 - Григорьева О. Образ учителя в советском кино: от «Весенней» оттепели до «Большой перемены» // Визуальная антропология: новые взгляды на социальную реальность / Под ред. Е. Р. Ярской-Смирновой, П. В. Романова, В. Л. Круткина. Саратов: Научная книга, 2007. С. 223-239.

Громов, 1982 - Громов E.C. Восхождение к герою (экран и молодежь). Книга для учителя. М.: Просвещение, 1982. 192 с.

Жарикова, 2015 - Жарикова В.В. Хронотоп школы в отечественном кинематографе // Исторические, философские, политические и юридические науки, культурология $u$ искусствоведение. Вопросы теории и практики. 2015. № 5 (55): в 2-х ч. Ч. II. С. 59-62.

Кабо, 1978 - Кабо Л.Р. Кино в эстетическом и нравственном воспитании детей. М.: Просвещение, 1978.

Кабо, 1974 - Кабо Л.Р. Кино и дети. М.: Знание, 1974. 96 с.

Левшина, 1978 - Левшина И.С. Любите ли вы кино? М.: Искусство, 1978. 254 с.

Левшина, 1989 - Левшина И.С. Подросток и экран. М.: Педагогика, 1989. 176 с.

Маченин, 2016 - Маченин А.А. Собирательный образ школьного учителя в отражении теле/кино/интернет медиапространства // Медиаобразование. 2016. № 3. С. 23-48.

Митина, 2015 - Митина T.C. Образ учителя в советском кинематографе первой половины двадцатого столетия // Сибирский научный вестник. 2015. № 2. С. 124-128.

Нусинова, 2003 - Нусинова $H$. «Теперь ты наша». Ребенок в советском кино 20-30-х годов // Искусство кино. 2003. № 12. С. 81-87.

Парамонова, 1975 - Парамонова К.К. Фильм для детей, его специфика и воспитательные функции. М.: ВГИК, 1975. 51 с. 
Парамонова, 1976 - Парамонова К.К. Фильм и дети. М., 1976.

Пензин, 1973 - Пензин С.Н. Кино как средство воспитания. Воронеж, 1973. 152 с.

Пензин, 1986 - Пензин С.Н. Уроки кино. М., 1986. 66 с.

Притуленко, 1995 - Притуленко В. Адресовано детям // Кино, политика и люди. зо-е годъ. М.: Материк, 1995. 229 с.

Рабинович, 1991 - Рабинович Ю.М. Кино, литература и вся моя жизнь. Курган: Периодика, 1991. 120 с.

Рабинович, 1969 - Рабинович Ю.М. Роль кино в воспитании школьников. Курган, 1969. $26 \mathrm{c}$.

Рыбак, 1980 - Рыбак Л.А. Наедине с фильмом. Об искусстве быть кинозрителем. М.: БПСК, 1980. $57 \mathrm{c.}$

Соловейчик, 1975 - Соловейчик С.Л. Учитель - профессия и судьба // Советский экран. 1975. № 20.

Строева, 1962 - Строева А.С. Дети, кино и телевидение. М.: Знание, 1962. 47 с.

Суспицына, 2002 - Суспицына T. Об учителе, муже и чине: (Ре)конструкция маскулинностей мужчин - работников средней школы // O муже $(N)$ ственности / Сост. С. Ушакин. М.: Новое литературное обозрение, 2002. С. 303-324.

Толстых, 1988 - Толстьх А.В. До 16 и старие... М.: Киноцентр, 1988. 64 с.

Усов, 2010 - Усов Ю.Н. Методика использования киноискусства в идейноэстетическом воспитании учащихся 8-10 классов. Таллин, 1980. 125 с.

Шипулина, 2010 - Шипулина Н.Б. Образ учителя в советском и современном российском кинематографе // Известия ВГПУ. 2010. № 8 (52). С. 4-16

Чащухин, 2006 - Чащухин А.B. Конструирование образа учителя в сталинской пропаганде 1945-1953 гг. // Человек. Общество. Управление. 2006. № 3. С. 132-135.

Ayers, 1994 - Ayers, W. (1994). A Teacher Ain't Nothin' But a Hero: Teachers and Teaching in Film. In Joseph, P., \& Burnaford, G. (Eds.). Images of Schoolteachers in Twentieth-Century America. New York: St. Martin's Press, pp. 147-156.

Bauer, 1998 - Bauer, D. (1998). Indecent Proposals: Teachers in the Movies. College English. 60 (3), pp.301-317.

Bell, 1996 - Bell, A. (1996). Approaches to media discourse. London: Blackwell.

Burbach, Figgins, 1993 - Burbach, H.J., Figgins, M.A. (1993). A Thematic Profile of the Images of Teachers in Film // Teacher Education Quarterly. Vol. 20, No. 2, pp. 65-75.

Considine, 1985 - Considine, D. (1985). The Cinema of Adolescence. Jefferson and London, UK: McFarland \& Company.

Crume, 1988 - Crume, M. (1988). Images of Teachers in Novels and Films for the Adolescent, 1980-1987. PhD. Dissertation, University of Florida.

Dalton, 1999 - Dalton, M. (1999). The Hollywood Curriculum: Teachers and Teaching in the Movies. New York: Peter Lang.

Dubois, 2007 - Dubois, $R$. (2007). Une histoire politique du cinema. Paris: Sulliver, 216 p.

Edelman, 1990 - Edelman, R. (1990). Teachers in the Movies. American Educator. N 7(3), pp. 26-31.

Farber, Holm, 1994 - Farber, P., Holm, G. (1994a). Adolescent Freedom and the Cinematic High School. In P. Farber, E. Provenzo, Jr., \& G. Holm, (Eds.). Schooling in the Light of Popular Culture. Albany, NY: State University of New York Press.

Farber, Holm, 1994 - Farber, P., Holm, G. (1994b). A Brotherhood of Heroes: The Charismatic Educator in Recent American Movies. In P. Farber, E. Provenzo, Jr., \& G. Holm, (Eds.) Schooling in the Light of Popular Culture. Albany, NY: State University of New York Press. Joseph, Burnaford, 1994 - Joseph, P., Burnaford, G. (1994). Contemplating Images of

Schoolteachers in American Culture. In P. Joseph \& G. Burnaford (Eds.). Images of Schoolteachers in Twentieth Century America. New York: St. Martin's Press.

Kenez, 1992 - Kenez, P. (1992). Cinema and Soviet Society, 1917-1953. Cambridge, N.Y.:

Cambridge University Press, 281 p.

Keroes, 1999 - Keroes, J. (1999). Tales Out of School: Gender, Longing, and the Teacher in

Fiction and Films. Carbondale and Edwardsville, IL: Southern Illinois University Press.

Lawton, 2004 - Lawton, A. (2004). Imaging Russia 2000. Films and Facts. Washington, DC:

New Academia Publishing, 348 p. 
Oliker, 1993 - Oliker, M.A. (1993). On the Images of Education in Popular Film. Educational Horizons. Vol. 71, No. 2.

Schwartz, 1963 - Schwartz, J. (1963). The Portrayal of Education in American Motion Pictures, 1931-1961. PhD. dissertation, University of Illinois, Champaign-Urbana.

Shaw, Youngblood, 2010 - Shaw, T. and Youngblood, D.J. (2010). Cinematic Cold War: The American and Soviet Struggle for Heart and Minds. Lawrence: University Press of Kansas, $301 \mathrm{p}$.

Shlapentokh, 1993 - Shlapentokh D. and V. (1993). Soviet Cinematography 1918-1991: Ideological Conflict and Social Reality. N.Y.: Aldine de Gruyter.

Strada, 1989 - Strada, M. (1989). A Half Century of American Cinematic Imagery: Hollywood's Portrayal of Russian Characters, 1933-1988. Coexistence. N 26, pp. 333-350.

Strada, Troper, 1997 - Strada, M.J., Troper, H.R. (1997). Friend or Foe? Russian in American Film and Foreign Policy. Lanham, Md., \& London: The Scarecrow Press, 255 p.

Trier, 2001 - Trier, J.D. (2001). The Cinematic Representation of the Personal and Professional Lives of Teachers. Teacher Education Quarterly, pp. 127-142.

\section{References}

Arkus, 2010 - Arkus L. (2010). Priklyucheniya beloi vorony: evolyutsiya «shkol'nogo fil'ma» $\mathrm{v}$ sovetskom kino [The adventures of the white crow: the evolution of the "school film" in Soviet cinema]. Seans. 2 iyunya. URL: http://seance.ru/blog/whitecrow/

Baranov, 1979 - Baranov O.A. (1979). Ekran stanovitsya drugom [The screen becomes a friend]. M.: Prosveshchenie, $96 \mathrm{~s}$.

Grigor'eva, 2007 - Grigor'eva O. (2007). Obraz uchitelya v sovetskom kino: ot «Vesennei» ottepeli do "Bol'shoi peremeny» [The image of a teacher in Soviet cinema: from the "Spring" thaw to "Big change"]. Vizual'naya antropologiya: novye vzglyady na sotsial'nuyu real'nost'. Pod red. E. R. Yarskoi-Smirnovoi, P. V. Romanova, V. L. Krutkina. Saratov: Nauchnaya kniga, S. 223-239.

Gromov, 1982 - Gromov E.S. (1982). Voskhozhdenie k geroyu (ekran i molodezh') [Ascent to the hero (screen and youth)]. Kniga dlya uchitelya. M.: Prosveshchenie, 1982. $192 \mathrm{s.}$

Zharikova, 2015 - Zharikova V.V. (2015). Khronotop shkoly v otechestvennom kinematografe [Chronotope of the school in the national cinema] Istoricheskie, filosofskie, politicheskie i yuridicheskie nauki, kul'turologiya i iskusstvovedenie. Voprosy teorii i praktiki. № 5 (55): v 2-kh ch. Ch. II. C. 59-62.

Kabo, 1978 - Kabo L.R. (1978). Kino v esteticheskom i nravstvennom vospitanii detei [Cinema in the aesthetic and moral education of childre]. M.: Prosveshchenie.

Kabo, 1974 - Kabo L.R. (1974). Kino i deti [Cinema and children]. M.: Znanie, 96 s.

Levshina, 1978 - Levshina I.S. (1978). Lyubite li vy kino? [Do you like movies?]. M.: Iskusstvo, $254 \mathrm{~s}$.

Levshina, 1989 - Levshina I.S. (1989). Podrostok i ekran [A teenager and a screen]. M.: Pedagogika, $176 \mathrm{~s}$.

Machenin, 2016 - Machenin A.A. (2016). Sobiratel'nyi obraz shkol'nogo uchitelya v otrazhenii tele/kino/internet mediaprostranstva [The Collective Image of the School Teacher in Reflection of the TV]. Mediaobrazovanie. № 3. C. 23-48.

Mitina, 2015 - Mitina T.S. (2015). Obraz uchitelya v sovetskom kinematografe pervoi poloviny dvadtsatogo stoletiya [The image of a teacher in the soviet cinema of the first half of the twentieth century]. Sibirskii nauchnyi vestnik. № 2. S. 124-128.

Nusinova, 2003 - Nusinova N. (2003). «Teper' ty nasha». Rebenok v sovetskom kino 20-30kh godov ["Now you are ours." A child in Soviet cinema 20-30-ies]. Iskusstvo kino. № 12. S. 81-87.

Paramonova, 1975 - Paramonova K.K. (1975). Fil'm dlya detei, ego spetsifika i vospitatel'nye funktsii [A film for children, its specificity and educational functions]. M.: VGIK, $51 \mathrm{~s}$.

Paramonova, 1976 - Paramonova K.K. (1976). Fil'm i deti [Film and children]. M.

Penzin, 1973 - Penzin S.N. (1973). Kino kak sredstvo vospitaniya [Cinema as a means of education]. Voronezh, $152 \mathrm{~s}$.

Penzin, 1986 - Penzin S.N. (1986). Uroki kino [Cinema lessons]. M., 66 s.

Pritulenko, 1995 - Pritulenko V. (1995). Adresovano detyam [Addressed to children]. Kino, politika i lyudi. 30-e gody. M.: Materik, $229 \mathrm{~s}$.

Rabinovich, 1991 - Rabinovich Yu.M. (1991). Kino, literatura i vsya moya zhizn' [Cinema, literature and all my life]. Kurgan: Periodika, 120 s. 
Rabinovich, 1969 - Rabinovich Yu.M. (1969). Rol' kino v vospitanii shkol'nikov [The role of cinema in the education of schoolchildren]. Kurgan, $26 \mathrm{~s}$.

Rybak, 1980 - Rybak L.A. (1980). Naedine s fil'mom. Ob iskusstve byt' kinozritelem [Alone with the film. On the art of being a moviegoer.]. M.: BPSK, $57 \mathrm{~s}$.

Soloveichik, 1975 - Soloveichik S.L. (1975). Uchitel' - professiya i sud'ba [Teacher profession and fate]. Sovetskii ekran. 1975. № 20.

Stroeva, 1962 - Stroeva A.S. (1962). Deti, kino i televidenie [Children, movies and television]. M.: Znanie, $47 \mathrm{~s}$.

Suspitsyna, 2002 - Suspitsyna T. (2002). Ob uchitele, muzhe i chine: (Re)konstruktsiya maskulinnostei muzhchin - rabotnikov srednei shkoly [About the teacher, husband and rank: (Re) the construction of masculinity of male workers of secondary school]. O muzhe(N)stvennosti / Sost. S. Ushakin. M.: Novoe literaturnoe obozrenie, S. 303-324.

Tolstykh, 1988 - Tolstykh A.V. (1988). Do 16 i starshe... [Up to 16 and older ...]. M.: Kinotsentr, $64 \mathrm{~s}$.

Usov, 1980 - Usov Yu.N. (1980). Metodika ispol'zovaniya kinoiskusstva v ideinoesteticheskom vospitanii uchashchikhsya 8-10 klassov [The technique of using film art in the ideological and aesthetic education of pupils of grades 8-10]. Tallin, $125 \mathrm{~s}$.

Shipulina, 2010 - Shipulina N.B. (2010). Obraz uchitelya v sovetskom i sovremennom rossiiskom kinematografe [The image of a teacher in soviet and modern russian cinema]. Izvestiya $V G P U$. № 8 (52). S. 4-16

Chashchukhin, 2006 - Chashchukhin A.V. (2006). Konstruirovanie obraza uchitelya v stalinskoi propagande 1945-1953 gg. [The construction of the teacher's image in the Stalinist propaganda of 1945-1953]. Chelovek. Obshchestvo. Upravlenie. № 3. S. 132-135.

Ayers, 1994 - Ayers, W. (1994). A Teacher Ain't Nothin' But a Hero: Teachers and Teaching in Film. In Joseph, P., \& Burnaford, G. (Eds.). Images of Schoolteachers in Twentieth-Century America. New York: St. Martin's Press, pp. 147-156.

Bauer, 1998 - Bauer, D. (1998). Indecent Proposals: Teachers in the Movies. College English. 60 (3), pp.301-317.

Bell, 1996 - Bell, A. (1996). Approaches to media discourse. London: Blackwell.

Burbach, Figgins, 1993 - Burbach, H.J., Figgins, M.A. (1993). A Thematic Profile of the Images of Teachers in Film // Teacher Education Quarterly. Vol. 20, No. 2, pp. 65-75.

Considine, 1985 - Considine, D. (1985). The Cinema of Adolescence. Jefferson and London, UK: McFarland \& Company.

Crume, 1988 - Crume, M. (1988). Images of Teachers in Novels and Films for the Adolescent, 1980-1987. PhD. Dissertation, University of Florida.

Dalton, 1999 - Dalton, $M$. (1999). The Hollywood Curriculum: Teachers and Teaching in the Movies. New York: Peter Lang.

Dubois, 2007 - Dubois, $R$. (2007). Une histoire politique du cinema. Paris: Sulliver, 216 p.

Edelman, 1990 - Edelman, R. (1990). Teachers in the Movies. American Educator. N 7(3), pp. 26-31.

Farber, Holm, 1994 - Farber, P., Holm, G. (1994a). Adolescent Freedom and the Cinematic High School. In P. Farber, E. Provenzo, Jr., \& G. Holm, (Eds.). Schooling in the Light of Popular Culture. Albany, NY: State University of New York Press.

Farber, Holm, 1994 - Farber, P., Holm, G. (1994b). A Brotherhood of Heroes: The Charismatic Educator in Recent American Movies. In P. Farber, E. Provenzo, Jr., \& G. Holm, (Eds.) Schooling in the Light of Popular Culture. Albany, NY: State University of New York Press.

Joseph, Burnaford, 1994 - Joseph, P., Burnaford, G. (1994). Contemplating Images of Schoolteachers in American Culture. In P. Joseph \& G. Burnaford (Eds.). Images of Schoolteachers in Twentieth Century America. New York: St. Martin's Press.

Kenez, 1992 - Kenez, P. (1992). Cinema and Soviet Society, 1917-1953. Cambridge, N.Y.:

Cambridge University Press, 281 p.

Keroes, 1999 - Keroes, J. (1999). Tales Out of School: Gender, Longing, and the Teacher in

Fiction and Films. Carbondale and Edwardsville, IL: Southern Illinois University Press.

Lawton, 2004 - Lawton, A. (2004). Imaging Russia 2000. Films and Facts. Washington, DC:

New Academia Publishing, 348 p.

Oliker, 1993 - Oliker, M.A. (1993). On the Images of Education in Popular Film. Educational 
Horizons. Vol. 71, No. 2.

Schwartz, 1963 - Schwartz, J. (1963). The Portrayal of Education in American Motion Pictures, 1931-1961. PhD. dissertation, University of Illinois, Champaign-Urbana.

Shaw, Youngblood, 2010 - Shaw, T. and Youngblood, D.J. (2010). Cinematic Cold War: The American and Soviet Struggle for Heart and Minds. Lawrence: University Press of Kansas, $301 \mathrm{p}$.

Shlapentokh, 1993 - Shlapentokh D. and V. (1993). Soviet Cinematography 1918-1991: Ideological Conflict and Social Reality. N.Y.: Aldine de Gruyter.

Strada, 1989 - Strada, M. (1989). A Half Century of American Cinematic Imagery: Hollywood's Portrayal of Russian Characters, 1933-1988. Coexistence. N 26, pp. 333-350.

Strada, Troper, 1997 - Strada, M.J., Troper, H.R. (1997). Friend or Foe? Russian in American Film and Foreign Policy. Lanham, Md., \& London: The Scarecrow Press, 255 p.

Trier, 2001 - Trier, J.D. (2001). The Cinematic Representation of the Personal and Professional Lives of Teachers. Teacher Education Quarterly, pp. 127-142.

\section{УДК 378}

\section{Количественная и жанровая динамика кинопроизводства советских и российских фильмов, связанных тематикой школы и вуза}

Александр Викторович Федоров а , *

а Ростовский государственный экономический университет, Российская Федерация

Аннотация. Период пик интереса к школьной/вузовской теме на советском/российском экране пришелся на так называемый период «застоя» (1969-1985), когда на экраны страны вышло 127 лент (36,4 \% от общего числа фильмов на эту тему). На втором месте идет российский период (1992-2017) - 93 лент (26,7 \%). Ощутимое снижение числа фильмов о школе и вузе отмечалось в 1990-х годах, и связано это было с общим уменьшением фильмопроизводства в России. В жанровом отношении в период с 1919 по 2017 год в школьной/вузовской кинотематике доминировали: драмы - 220 (63,0 \%), комедии - 82 (23,5\%), мелодрамы - 36 (10,3\%).

Драматический жанр особенно преобладал (около 90 \% всех фильмов о школе и вузе) в период 1919-1955 годов и во времена «перестройки», тогда как пики производства кинокомедий пришлись на российский период: 41 \% всех фильмов на школьно-вузовскую тему и период «застоя», когда такого рода ленты составляли четвертую часть. Доминанта драмы вполне объяснима - в советские времена не только школьно-вузовские сюжеты, но кинематограф в целом был ориентирован, прежде всего, именно на драматический жанр. Комедий и мелодрам становилось больше именно в годы относительной общественной стабильности, в то время как драматические сюжеты доминировали в годы, когда в социуме преобладала конфронтация.

Ключевые слова: фильм, СССР, Россия, школьная тема, школа, вуз, школьник, ученик, учитель, кинематограф.

\footnotetext{
${ }^{*}$ Корреспондирующий автор

Адрес электронной почты: 1954alex@mail.ru (А.В. Федоров)
} 


\section{Приложения}

\section{Советские и российские фильмы и сериалы о школе и вузе (фильмографии)}

Дети и молодежь появлялись в качестве персонажей в сотнях советских и российских фильмов. В данный список включены не просто фильмы с персонажамидетьми/школьниками / студентами, а те фильмы, где заметное положение занимает именно школьная и вузовская тема. Исключения сделаны в основном для некоторых значимых для темы воспитания подрастающего поколения фильмов (например, действие которых происходит в летних лагерях отдыха для школьников).

\section{Фильмография советских фильмов о школе и вузе}

$$
\text { 1919-1930 }
$$

\section{4}

Ванька - юный пионер. СССР, 1924. Режиссер и сценарист Пётр Малахов. Актеры: Шура Константинов, Урсула Круг, Алексей Масеев и др. Драма.

Остров юных пионеров. СССР, 1924. Режиссер Алексей Ган. Сценарист и исполнитель главной роли Владимир Веревкин. Агитфильм.

\section{5}

Федькина правда. СССР, 1925. Режиссер Ольга Преображенская. Сценаристы: Николай Асеев, Александр Перегуда. Актеры: Юрий Зимин, Марик Майя, Даниил Введенский, Елена Дейнеко и др. Драма.

\section{8}

Золотой мед. СССР, 1928. Режиссеры: Николай Береснев, Владимир Петров. Сценарист Драма.

Николай Береснев. Актеры: Федор Богданов, Пётр Кузнецов, Фатима Гилязова и др.

Маленькие и болышие. СССР, 1928. Режиссер Дмитрий Бассалыго. Сценаристы: Дмитрий Бассалыго, Александр Филимонов. Актеры: Ольга Третьякова, Иван Капралов, Сергей Минин и др. Драма.

Оторванные рукава. СССР, 1928. Режиссер Б. Юрцев. Сценаристы: Иван Пырьев, Борис Юрцев. Актеры: Александр Жуков, Лебедев, Серпуховитин, Александр Сафронов и др. Драма.

\section{9}

Танька-трактирщица. СССР, 1929. Режиссер Борис Светозаров. Сценаристы: Борис Светозаров, Константин Минаев. Актеры: Неонила Иванова-Толмачёва, Кузьма Ястребецкий, Любовь Ненашева и др. Драма.

Человек с портфелем. СССР, 1929. Режиссер Чеслав Сабинский. Сценарист А. Кириллов (автор пьесы - А. Файко). Актеры: Николай Монахов, Ирина Володко, Коля Симонович и др. Драма.

\section{0}

Право на женщину / Студентка. СССР, 1930. Режиссер Алексей Каплер. Сценаристы: Алексей Каплер, Николай Бажан. Актеры: Татьяна Златогорова, Владимир Сокирко, Иван Скуратов, Таня Мухина и др. Драма.

Право отцов. СССР, 1930. Режиссер Вера Строева. Сценаристы: Вера Строева, Станислав Уэйтинг-Радзинский, Серафима Рошаль. Актеры: И. Трердохлеб, Г. Ростов и др. Драма. 


\section{1-1955}

1931

Путевка в жизнь. СССР, 1931. Режиссер Николай Экк. Сценаристы: Александр Столпер, Николай Экк, Регина Янушкевич. Актеры: Йыван Кырля, Михаил Джагофаров, Александр Новиков, Николай Баталов, Мария Антропова, Михаил Жаров и др. Драма.

Человек без футляра. СССР, 1931. Режиссер Вера Строева. Сценаристы: Серафима Рошаль, Вера Строева. Актеры: Борис Фердинандов, Михаил Викторов, Николай Надемский и др. Драма.

1932

Поздравляю с переходом. СССР, 1932. Режиссер и сценарист Евгения Григорович. Актеры: С. Пельтик, Т. Зайченко, Иван Твердохлеб и др. Драма.

Сенька с "Мимозы". СССР, 1932. Режиссер Алексей Маслюков. Сценаристы: Николай Сказбуш, Алексей Маслюков. Актеры: Витя Фридрих, Борис Безгин, Николай Надемский. Драма.

1933

Отчаянный батальон. СССР, 1933. Режиссеры и сценаристы: Абрам Народицкий, Наум Угрюмов. Актеры: Геннадий Мичурин, Роза Свердлова и др. Драма.

1934

Разбудите Леночку. СССР, 1934. Режиссер Антонина Кудрявцева. Сценаристы: Николай Олейников, Евгений Шварц. Актеры: Янина Жеймо, Сергей Герасимов и др. Комедия.

1935

Кондуит. СССР, 1935. Режиссер Борис Шелонцев. Сценаристы: Лев Кассиль, Лазарь Юдин (автор повести "Кондуит и Швамбрания" - Л. Кассиль). Актеры: А. Кобзев, Е. Борисевич, Владимир Гардин и др. Драма.

1936

Настоящий товарищ. СССР, 1936. Режиссеры: Лазарь Бодик, Абрам Окунчиков. Сценарист Агния Барто. Актеры: Михаил Тарханов, Степан Шагайда, Дмитрий Голубинский и др. Драма.

1937

Буйная ватага. СССР, 1937. Режиссеры: Александр Попов, Гамар Саламзаде. Сценарист

Юрий Фидлер. Актеры: А. Варганова, Муртаза Ахмедов, А. Багирова и др. Комедия.

\section{8}

Семиклассники. СССР, 1938. Режиссеры: Яков Протазанов, Григорий Левкоев. Сценаристы: Наум Кауфман, В. Любимова. Актеры: Юра Митаев, Александр Зражевский, Анна Запорожец, Николай Гладков и др. Драма.

1939

Личное дело. СССР, 1939. Режиссер Александр Разумный. Сценаристы: Аркадий Гайдар, В. Поташев. Актеры: Лора Минаев, Петя Гроховский, Борис Рунге, Лев Мирский и др. Драма.

Учитель. СССР, 1939. Режиссер и сценарист Сергей Герасимов. Актеры: Борис Чирков, Тамара Макарова, Павел Волков и др. Драма.

Человек в футляре. СССР, 1939. Режиссер и сценарист Исидор Анненский. Актеры: Николай Хмелев, Михаил Жаров, Ольга Андровская, Владимир Гардин, Фаина Раневская, Алексей Грибов и др. Драма. 
1940

Брат героя. СССР, 1940. Режиссер Юрий Васильчиков. Сценарист Лев Кассиль (автор «Черемыш - брат героя» - Л. Кассиль). Актеры: Николай Крючков, Петр Леонтьев, Елизавета Найденова и др. Драма.

Весенний поток. СССР, 1940. Режиссёр Владимир Юренев. Актеры: Александр Зражевский, Михаил Астангов, Валентина Серова и др. Драма.

Закон жизни. СССР, 1940. Режиссеры: Александр Столпер, Борис Иванов. Сценарист Александр Авдеенко. Актеры: Даниил Сагал, Александр Лукьянов, Освальд Глазунов, Нина Зорская и др. Драма.

Приятели. СССР, 1940. Режиссер Михаил Гавронский. Сценарист Николай Таубе. Актеры: Михаил Кузнецов, Тамара Алёшина, Владимир Гардин, Василий Меркурьев, Константин Сорокин, и др. Драма.

Тимур и его команда. СССР, 1940. Режиссер Александр Разумный. Сценарист Аркадий Гайдар. Актеры: Ливий Щипачёв, Пётр Савин, Лев Потёмкин, Виктор Селезнёв, Петя Гроховский и др. Драма.

1941

Романтики. СССР, 1941. Режиссер Марк Донской. Сценаристы: Тихон Семушкин, Федор Кнорре. Актеры: Даниил Сагал, Дарига Тналина, Ирина Федотова, Владимир Владиславский, Лев Свердлин и др. Драма.

1947

Сельская учительница. СССР, 1947. Режиссер Марк Донской. Сценарист Мария Смирнова. Актеры: Вера Марецкая, Даниил Сагал, Павел Оленев, Владимир Марута, Владимир Белокуров и др. Драма.

\section{8}

Красный галстук. СССР, 1948. Режиссеры: Владимир Сухобоков, Мария Сауц. Сценарист и автор одноименной пьесы Сергей Михалков. Актеры: Александр Соколов, Ирина Начинкина, Слава Котов, Анатолий Ганичев, Александр Хвыля и др. Драма.

Первоклассница. СССР, 1948. Режиссер Илья Фрэз. Сценарист Евгений Шварц. Актеры: Наталья Защипина, Тамара Макарова, Кира Головко и др. Драма.

1952

Навстречу жизни. СССР, 1952. Режиссер Николай Лебедев. Сценарист Екатерина Виноградская (автор повести «Звездочка» - Иван Василенко). Актеры: Надежда Румянцева, Владимир Соколов, Георгий Семёнов, Василий Меркурьев, Сергей Гурзо, Виктор Хохряков, Анатолий Кузнецов и др. Драма.

\section{3}

Алеша Птицын вырабатывает характер. СССР, 1953. Режиссер Анатолий Граник. Сценарист Агния Барто. Актеры: Виктор Каргопольцев, Ольга Пыжова, Валентина Сперантова, Наталья Селезнёва, Надежда Румянцева и др. Комедия.

Честь товарища. ССCP, 1953. Режиссер Николай Лебедев. Сценаристы: Борис Изюмский, Леонид Жежеленко (автор повести «Алые погоны» - Б. Изюмский). Актеры: Константин Скоробогатов, Борис Коковкин, Геннадий Мичурин, Владимир Дружников, Юрий Толубеев и др. Драма.

\section{4}

Аттестат зрелости. СССР, 1954. Режиссер Татьяна Лукашевич. Сценарист и автор одноименной повести Лия Гераскина. Актеры: Василий Лановой, Вадим Грачёв, Галина Ляпина, Тамара Кирсанова и др. Драма.

Два друга. СССР, 1954. Режиссер Виктор Эйсымонт. Сценарист Николай Носов (автор повести «Витя Малеев в школе и дома» - Н. Носов). Актеры: Леонид Крауклис, Владимир Гуськов, Миша Аронов, Витя Белов, Янина Жеймо и др. Драматическая комедия.

Сёстры Рахмановы. СССР, 1954. Режиссер Камил Ярматов. Сценарист Владимир 
Швейцер. Актеры: Сара Ишантураева, Яйра Абдулаева, Юлдуз Ризаева и др. Драма.

1955

Васек Трубачев и его товарищи. СССР, 1955. Режиссеры: Илья Фрэз, Эдуард Бочаров.

Сценаристы: Валентина Осеева-Хмелева, Борис Старшев (автор повести - В. Осеева). Актеры: Олег Вишнев, Саша Чудаков, Вова Семенович, Слава Девкин, Жора Александров, Наталья Рычагова, Леонид Харитонов, Иван Пельтцер, Юрий Медведев, Пётр Алейников и др. Драма.

Два капитана. СССР, 1955. Режиссер Владимир Венгеров. Сценаристы: Вениамин Каверин, Евгений Габрилович (автор одноименного романа - В. Каверин). Актеры: Александр Михайлов, Ольга Заботкина, Анатолий Адоскин, Евгений Лебедев, Борис Беляев и др. Драма.

Педагогическая поэма. ССCP, 1955. Режиссеры: Мечислава Маевская, Алексей Маслюков. Сценаристы: Иосиф Маневич, Алексей Маслюков (автор одноименного романа Антон Макаренко). Актеры: Владимир Емельянов, Михаил Покотило, Елена Лицканович, Нина Крачковская, Константин Михайлов, Павел Кадочников, Георгий Юматов, Юрий Саранцев, Юлиан Панич и др. Драма.

Сын. СССР, 1955. Режиссер Юрий Озеров. Сценарист Татьяна Сытина. Актеры: Леонид Харитонов, Пётр Константинов, Варвара Каргашёва, Виктор Гераскин, Надежда Румянцева, Константин Сорокин, Алексей Грибов, Владимир Белокуров, Роза Макагонова и др. Драма.

1956

$$
\text { 1956-1968 }
$$

Весна на заречной улице. СССР, 1956. Режиссеры: Феликс Миронер, Марлен Хуциев. Сценарист Феликс Миронер. Актеры: Нина Иванова, Николай Рыбников, Владимир Гуляев, Валентина Пугачёва, Геннадий Юхтин и др. Мелодрама.

Разные судьбы. СССР, 1956. Режиссер Леонид Луков. Сценаристы: Леонид Луков, Яков Смоляк. Актеры: Татьяна Пилецкая, Юлиан Панич, Лев Свердлин, Ольга Жизнева, Татьяна Конюхова, Георгий Юматов, Ада Войцик, Владимир Дорофеев, Сергей Блинников, Валентина Ушакова, Константин Сорокин, Всеволод Санаев, Бруно Фрейндлих и др. Драма.

1957

Они встретились в пути. СССР, 1957. Режиссер Татьяна Лукашевич. Сценарист Леонид Пантелеев. Актеры: Виктор Авдюшко, Роза Макагонова, Николай Комиссаров, Миша Меркулов, Нина Дорошина, Пётр Щербаков, Вера Васильева и др. Мелодрама.

Повесть о первой любви. СССР, 1957. Режиссер Василий Левин. Сценарист Мария Смирнова (автор повести Н. Атаров). Актеры: Джемма Осмоловская, Кирилл Столяров, Владимир Земляникин, Сергей Столяров и др. Мелодрама.

1958

Город зажигает огни. СССР, 1958. Режиссер и сценарист Владимир Венгеров. Актеры: Николай Погодин, Елена Добронравова, Олег Борисов, Лилиана Алешникова, Юрий Любимов, Алиса Фрейндлих и др. Драма.

Сверстницы. СССР, 1958. Режиссер Василий Ордынский. Сценарист Алла Белякова. Актеры: Лидия Федосеева-Шукшина, Людмила Крылова, Маргарита Кошелева, Владимир Костин, Всеволод Сафонов, Кирилл Столяров и др. Драма.

Флаги на башнях. CCCP, 1958. Режиссер Абрам Народицкий. Сценарист Иосиф Маневич. Актеры: Владимир Емельянов, Владимир Судьин, Константин Доронин, Илья Милютенко, Роза Макагонова, Ада Роговцева и др. Драма.

1959

Мальчики. СССР, 1959. Режиссер Суламифь Цыбульник. Сценаристы: Анна Лисянская, Дора Вольперт. Актеры: Лёня Бабич, Николай Чурсин, Саша Карпов, Лидия Сухаревская и др. Драма. 
На пороге жизни. СССР, 1959. Режиссер Константин Пипинашвили. Сценарист Юрий Кротков. Актеры: Лейла Абашидзе, Отар Хатиашвили, Гоча Абашидзе и др. Драма.

Это было весной. СССР, 1959. Режиссеры: Артур Войтецкий, Карл Гаккель. Актеры: Людмила Бутенина, Лев Жуков и др. Драма. Воронин.

До будущей весны. СССР, 1960. Режиссер Виктор Соколов. Сценарист Сергей

Актеры: Людмила Марченко, Иннокентий Смоктуновский, Валентин Архипенко и др. Мелодрама.

\section{0}

Тучи над Борском. СССР, 1960. Режиссер Василий Ордынский. Сценаристы: Семён Лунгин, Илья Нусинов. Актеры: Инна Гулая, Роман Хомятов, Владимир Ивашов, Наталья Антонова, Виктор Рождественский, Инна Чурикова и др. Драма.

Чудотворная. СССР, 1960. Режиссер Владимир Скуйбин. Сценарист Владимир Тендряков. Актеры: Владимир Васильев, Нина Меньшикова, Антонина Павлычева, Клавдия Половикова, Владимир Покровский, Иван Рыжов, Станислав Чекан и др. Драма.

\section{1}

А если это любовь? СССР, 1961. Режиссер Юлий Райзман. Сценаристы: Иосиф Ольшанский, Юлий Райзман, Нина Руднева. Актеры: Жанна Прохоренко, Игорь Пушкарёв, Александра Назарова, Нина Шорина и др. Драма.

Друг мой, Колька! СССР, 1961. Режиссеры: Александр Митта, Алексей Салтыков. Сценаристы: Сергей Ермолинский, Александр Хмелик (автор одноименной пьесы А. Хмелик). Актеры: Александр Кобозев, Анна Родионова, Анатолий Кузнецов, Савелий Крамаров, Борис Новиков и др. Драма.

Мишка, Серега и я. СССР, 1961. Режиссер Георгий Победоносцев. Сценаристы: Ниссон Зелеранский, Борис Ларин. Актеры: Юрий Цветов, Виктор Семёнов, Валерий Рыжаков, Василий Шукшин, Владимир Гусев и др. Драма.

\section{2}

Грешный ангел. СССР, 1962. Режиссер Геннадий Казанский. Сценарист Михаил Берестинский. Актеры: Ольга Красина, Николай Волков (ст.), Нина Веселовская, Геннадий Фролов, Юрий Медведев, Борис Чирков, Галина Волчек и др. Драма.

Бей, барабан! СССР, 1962. Режиссер Алексей Салтыков. Сценаристы: Сергей Ермолинский, Александр Хмелик. Актеры: Алексей Крыченков, Люся Слепнева, Александр Демьяненко, Савелий Крамаров, Татьяна Конюхова и др. Драма.

Дикая собака Динго. СССР, 1962. Режиссер Юлий Карасик. Сценарист Анатолий Гребнев (автор одноименной повести - Р. Фраерман). Актеры: Галина Польских, Владимир Особик, Талас Умурзаков, Анна Родионова и др. Драма.

Маленькие мечтатели. СССР, 1962. Режиссеры: Олег Гречихо, Виктор Туров, Арсений Ястребов. Сценаристы: Елена Каплинская, Валентин Морозов, Нелли Морозова, Лилия Неменова, Геннадий Шпаликов. Актеры: Борис Битюков, Георгий Жжёнов, Ира Кривошанова и др. Драма.

Мы вас любим. СССР, 1962. Режиссер Эдуард Бочаров. Сценарист Сергей Михалков. Актеры: Александр Барсов, Вова Фурманкевич, Алеша Абрамов и др. Драма.

Приходите завтра. СССР, 1962. Режиссер и сценарист Евгений Ташков. Актеры: Екатерина Савинова, Анатолий Папанов, Юрий Горобец, Антонина Максимова, Надежда Животова, Александр Ширвиндт, Юрий Белов, Борис Бибиков и др. Комедия.

\section{3}

Большие и маленькие. СССР, 1963. Режиссер Мария Фёдорова. Сценарист Иосиф Маневич. Актеры: Олеся Иванова, Василий Горчаков, Нина Меньшикова, Николай Бармин, Лев Свердлин, Любовь Виролайнен, Василий Ливанов и др. Драма.

Маленькие рыцари. СССР, 1963. Режиссеры: Нинель Ненова-Цулая, Гено Цулая. Сценарист: Эдишер Кипиани. Актеры: Додо Чоговадзе, Дато Гиоргадзе, Нино Натадзе и др. Драма. 
Меня зовут Кожа. СССР, 1963. Режиссер Абдулла Карсакбаев. Сценарист Ниссон Зелеранский. Актеры: Нурлан Сегизбаев, М. Кокенов, Гульнар Курабаева и др. Комедия.

Случай в Даш-Кале. СССР, 1963. Режиссер Меред Атаханов. Сценаристы: Морис Симашко, Николай Фигуровский. Актеры: Куллук Ходжаев, Дурды Сапаров, Аннагуль Аннакулиева и др. Драма.

Трудные дети. СССР, 1963. Режиссер Всеволод Цветков. Сценарист Юрий Сотник. Актеры: Александр Кекиш, Гена Бирюков, Татьяна Пельтцер и др. Комедия.

Улица Ньютона, дом 1. СССР, 1963. Режиссер Теодор Вульфович. Сценаристы: Теодор Вульфович, Эдвард Радзинский. Актеры: Юрий Ильенко, Лариса Кадочникова, Евгений Фридман, Евгений Агафонов и др. Драма.

1964

Добро пожаловать, или Посторонним вход воспрещен! СССР, 1964. Режиссер Элем Климов. Сценаристы: Семён Лунгин, Илья Нусинов. Актеры: Евгений Евстигнеев, Арина Алейникова, Илья Рутберг, Лидия Смирнова, Алексей Смирнов, Виктор Косых и др. Комедия.

\section{5}

Вниманию граждан и организаций. СССР, 1965. Режиссер Артур Войтецкий. Сценарист Олег Прокопенко. Актеры: Виталий Беляков, Антоша Сочивко, Юрий Леонидов и др. Драма.

Звонят, откройте дверь. СССР, 1965. Режиссер Александр Митта. Сценарист Александр Володин. Актеры: Елена Проклова, Ролан Быков, Владимир Белокуров, Сергей Никоненко, Ольга Семёнова, Виктор Косых и др. Драма.

Мимо окон идут поезда. СССР, 1965. Режиссеры: Эдуард Гаврилов, Валерий Кремнев. Сценаристы: Любовь Кабо, Александр Хмелик. Актеры: Лев Круглый, Мария Стерникова, Элла Некрасова и др. Драма. Гайдай.

Наваждение. СССР, 1965 (новелла из фильма «Операция «Ы»). Режиссер Леонид

Сценаристы: Яков Костюковский, Морис Слободской, Леонид Гайдай. Актеры: Александр Демьяненко, Наталья Селезнёва, Виктор Павлов и др. Комедия.

Первая Бастилия. СССР, 1965. Режиссер Михаил Ершов. Сценарист Юрий Яковлев. Актеры: Валерий Головненков, Елизавета Солодова, Евгений Матвеев и др. Драма.

\section{6}

Первый учитель. СССР, 1966. Режиссер Андрей Кончаловский. Сценаристы: Чингиз Айтматов, Борис Добродеев, Андрей Кончаловский (автор одноименной повести Ч. Айтматов). Актеры: Болот Бейшеналиев, Наталья Аринбасарова, Д. Куюкова, И. Ногайбаев и др. Драма.

Республика ШКИД. СССР, 1966. Режиссер Геннадий Полока. Сценарист Леонид Пантелеев. Актеры: Сергей Юрский, Юлия Бурыгина, Павел Луспекаев, Александр Мельников, Анатолий Столбов и др. Драматическая комедия.

Тени старого замка. СССР, 1966. Режиссер Мария Муат. Актеры: Л. Губанов, В. Муравьев, М. Болдуман, Ю. Пузырев, Ю. Лученко и др. Детектив.

Три с половиной дня из жизни Ивана Семёнова, второклассника и второгодника. СССР, 1966. Режиссер Константин Березовский. Сценарист Лев Давыдычев. Актеры: Владимир Воробей, Елена Калашникова, Борис Ихлов и др. Комедия.

\section{7}

Личная жизнь Кузяева Валентина. СССР, 1967. Режиссеры: Илья Авербах, Игорь Масленников. Сценарист Наталья Рязанцева. Актеры: Виктор Ильичёв, Тамара Коновалова, Инна Сергеева и др. Драма. Актеры:

Я вас любил... СССР, 1967. Режиссер Илья Фрэз. Сценарист Михаил Львовский.

Виктор Перевалов, Виолетта Хуснулова, Виталий Ованесов, Лора Умарова, Валерий Рыжаков, Евгений Весник, Наталья Селезнёва и др. Комедийная мелодрама. 


\section{8}

Гольфстрим. СССР, 1968. Режиссер Владимир Довгань. Сценарист Олег Прокопенко. Актеры: Николай Бурляев, Валентин Марченко, Елена Легурова, Георгий Вицин и др. Драма.

Доживем до понедельника. СССР, 1968. Режиссер Станислав Ростоцкий. Сценарист Георгий Полонский. Актеры: Вячеслав Тихонов, Ирина Печерникова, Нина Меньшикова, Михаил Зимин, Ольга Жизнева, Ольга Остроумова, Игорь Старыгин, Юрий Чернов, Любовь Соколова и др. Драма.

Когда я был маленьким. СССР, 1968. Режиссер Альгирдас Араминас. Сценаристы Альгирдас Араминас, Ицхокас Мерас. Актеры: Линас Крищюнас, Юлия Каваляускайте, Элена Ремишаускене и др. Мелодрама.

Мужской разговор. СССР, 1968. Режиссер Игорь Шатров. Сценаристы: Валентин Ежов, Вадим Фролов (автор повести «Что к чему» - В. Фролов). Актеры: Николай Яхонтов, Александр Кавалеров, Василий Шукшин, Нинель Мышкова, Леонид Куравлёв и др. Драма.

Переходный возраст. СССР, 1968. Режиссер Ричард Викторов. Сценарист Александр Хмелик. Актеры: Елена Проклова, Сережа Макеев, Виталий Сегеда, Александр Барский, Лена Беспалова, Игорь Ледогоров и др. Драма.

Урок литературы. СССР, 1968. Режиссер Алексей Коренев. Сценарист Виктория Токарева (автор рассказа «День без вранья» - В. Токарева). Актеры: Евгений Стеблов, Леонид Куравлёв, Инна Макарова, Валентина Малявина, Евгений Леонов, Лариса Пашкова, Любовь Добржанская, Готлиб Ронинсон, Виктория Фёдорова, Николай Парфёнов и др. Комедия.

\section{9-1985}

\section{9}

Завтра, третьего апреля... СССР, 1969. Режиссер Игорь Масленников. Сценарист Владимир Валуцкий. Актеры: Слава Горошенков, Наталья Данилова, Женя Малянцев, Лариса Малеванная, Александр Демьяненко, Виктор Ильичёв, Павел Луспекаев, Константин Райкин и др. Комедия.

Мальчишки. СССР, 1969. Режиссеры: Леонид Макарычев, Аян Шахмалиева. Актеры: Андрей Константинов, Виктор Жуков, Майя Булгакова и др. Драма.

Я помню тебя, учитель. СССР, 1969. Режиссер Гасан Сеидбейли. Сценарист Максуд Ибрагимбеков. Актеры: Сулейман Алескеров, Насиба Зейналова, Шафига Мамедова и др. Драма.

1970

Внимание, черепаха! CССР, 1970. Режиссер Ролан Быков. Сценаристы: Семён Лунгин, Илья Нусинов. Актеры: Галина Буданова, Алексей Ершов, Андрей Самотолкин, Михаил Мартиросян, Алексей Баталов, Ирина Азер и др. Драма.

Волшебная сила. СССР, 1970. Режиссер Наум Бирман. Сценарист Виктор Драгунский.

Актеры: Людмила Сенчина, Николай Трофимов, Костя Цепкаев, Людмила Васютинская, Игорь Богданов, Нина Ургант, Татьяна Доронина, Аркадий Райкин и др. Комедия.

Золотые часы. СССР, 1970. Режиссер Марк Толмачёв. Сценарист Леонид Пантелеев. Актеры: Андрей Никонов, Олег Шорин, Виктор Глазырин, Алексей Смирнов, Савелий Крамаров и др. Драма.

Переступи порог. СССР, 1970. Режиссер Ричард Викторов. Сценарист Анатолий Гребнев. Актеры: Евгений Карельских, Ирина Короткова, Константин Кошкин, Наталья Рычагова, Михаил Любезнов и др. Драма.

Тайна железной двери. СССР, 1970. Режиссер Михаил Юзовский. Сценарист Александр Рейжевский (автор повести «Шел по городу волшебник» Ю.Томин). Актеры: Эвальдас Микалюнас, Андрей Харыбин, Алиса Фрейндлих, Олег Табаков, Савелий Крамаров и др. Фантастическая комедия. 
1971

Маленькая исповедь. СССР, 1971. Режиссер Альгирдас Араминас. Сценаристы: Альгирдас Араминас, Ицхокас Мерас (автор повести «Арберон» В. Бубнис). Актеры: Андрюс Карка, Рута Сталилюнайте, Гедиминас Карка и др. Драма.

Ох, уж эта Настя. СССР, 1971. Режиссер Юрий Победоносцев. Сценарист Валентина Спирина. Актеры: Ира Волкова, Таня Невская, Сергей Кусков, Наталья Гвоздикова, Нина Архипова и др. Комедия.

«Тигры» на льду. СССР. 1971. Режиссеры: Валентин Козачков, Альберт Осипов. Сценаристы: Виктор Мережко, Николай Горбунов. Актеры: Юля Корнева, Витя Снорков, Дима Сосновский, Саша Кривенко, Наталья Фатеева, Владимир Грамматиков и др. Драма.

1972

Береги друга. СССР, 1972. Режиссеры: Мухтар Ага-Мирзаев, Исан Каримов. Сценаристы: Владимир Барабаш, Ярослав Филиппов. Драма.

Большая перемена. СССР, 1972. Режиссер Алексей Коренев. Сценаристы: Алексей Коренев, Георгий Садовников. Актеры: Михаил Кононов, Евгений Леонов, Ролан Быков, Александр Збруев, Светлана Крючкова, Юрий Кузьменков, Савелий Крамаров, Наталия Богунова, Наталья Гвоздикова, Виктор Проскурин, Валерий Носик, Нина Маслова, Ирина Азер, Людмила Касаткина, Валентина Талызина, Михаил Яншин, Лев Дуров, Люсьена Овчинникова и др. Комедия.

Очкарик. СССР, 1972. Режиссёр Альгимантас Видугирис. В ролях: Кубанычбек Алыбаев, Бермета Маликова, Олег Каркавцев и др. Драма.

Перевод с английского. СССР, 1972. Режиссер Инесса Селезнёва. Сценаристы: Георгий Полонский, Наталья Долинина. Актеры: Майя Булгакова, Георгий Тараторкин, Андрей Тенета, Армен Джигарханян, Валентина Талызина и др. Драма.

Точка, точка, запятая... СССР, 1972. Режиссер Александр Митта. Сценаристы: Михаил Львовский, Александр Митта. Актеры: Сергей Данченко, Миша Козловский, Юрий Никулин, Евгений Герасимов, Владимир Заманский, Жанна Прохоренко и др. Комедия.

Учитель пения. СССР, 1972. Режиссер Наум Бирман. Сценарист Эмиль Брагинский. Актеры: Андрей Попов, Людмила Иванова, Ирина Алфёрова, Константин Кошкин, Евгений Евстигнеев, Людмила Аринина, Александр Демьяненко, Георгий Штиль и др. Комедия.

Чудак из пятого "Б". СССР, 1972. Режиссер Илья Фрэз. Сценарист Владимир Железников. Актеры: Андрей Войновский, Роза Агишева, Татьяна Пельтцер, Нина Корниенко, Николай Мерзликин, Евгений Весник и др. Комедия.

Юлька. СССР, 1972. Режиссер Константин Жук. Сценарист Евгения Рудых. Актеры: Ирина Варлей, Виктор Царьков, Сергей Проханов и др. Драма.

1973

Весёлые истории. СССР, 1973. Режиссеры: Альгимантас Кундялис, Гитис Лукшас, Стасис Мотеюнас. Сценарист и автор рассказов Николай Носов. Актеры: Дайва Дауётите, Алёша Денисов, Артурас Правилонис и др. Комедия.

Каждый вечер после работы. СССР, 1973. Режиссер Константин Ершов. Сценаристы: Константин Ершов, Олег Прокопенко (автор повести «Елена Николаевна» М. Глушко). Актеры: Зинаида Славина, Александр Граве, Ирина Бунина, Николай Гринько и др. Драма.

Капля в море. СССР, 1973. Режиссер и сценарист Яков Сегель. Актеры: Саша Масленников, Валентина Телегина, Лилиана Алешникова, Арина Алейникова, Зоя Фёдорова и др. Комедия.

Пожар во флигеле, или подвиг во льдах. СССР, 1973. Режиссер Евгений Татарский. Сценарист Валерий Попов (автор рассказов - В. Драгунский). Актеры: Саша Михайлов, Саша Хмельницкий, Олег Даль и др. Комедия.

Разные люди. СССР, 1973. Режиссер: Геннадий Павлов. Сценарист Наталья Долинина. Актеры: Владимир Иванов, Виталий Ованесов, Алла Богина, Александр Бордуков, Геннадий Сайфулин, Ирина Муравьёва, Борис Чирков, Наталья Сайко и др. Драма. 
1974

Валькины паруса. СССР, 1974. Режиссер Николай Жуков. Сценарист Валентина Спирина. Актеры: Андрей Цепкало, Феликс Смирнов, Гера Котовский и др. Драма.

Весенние перевертыши. СССР, 1974. Режиссер Григорий Аронов. Сценарист и автор одноименной повести Владимир Тендряков. Актеры: Роман Мадянов, Лариса Малеванная, Николай Пеньков, Лев Дуров, Николай Гринько и др. Драма.

Земные и небесные приключения. СССР, 1974. Режиссер Игорь Ветров. Сценарист Юрий Пархоменко. Актеры: Анатолий Матешко, Елена Плюйко, Валерий Провоторов, Елизавета Дедова, Михаил Глузский, Лаймонас Норейка, Глеб Стриженов и др. Драма.

Кыш и двапортфеля. СССР, 1974. Режиссер Эдуард Гаврилов. Сценарист Юз (Иосиф) Алешковский. Актеры: Андрей Кондратьев, Катя Кузнецова, Леонид Куравлёв, Лариса Лужина, Владимир Заманский, Людмила Гладунко и др. Комедия.

Лжинка, или Маленькая ложь и большие неприятности. СССР, 1974. Режиссер: Алла Сурикова. Актеры: Володя Пустовит, Зорий Коваль, Маргарита Кошелева и др. Мюзикл.

Не болит голова у дятла. СССР, 1974. Режиссер Динара Асанова. Сценарист Юрий Клепиков. Актеры: Александр Жезляев, Елена Цыплакова, Александр Богданов, Ира Обольская, Екатерина Васильева, Николай Гринько и др. Драма.

Такие высокие горы. СССР, 1974. Режиссер Юлия Солнцева. Сценарист Валентина Никиткина. Актеры: Сергей Бондарчук, Константин Смирнов, Ирина Скобцева и др. Драма.

1975

Дневник директора школы. СССР, 1975. Режиссер Борис Фрумин. Сценарист Анатолий Гребнев. Актеры: Олег Борисов, Ия Саввина, Алла Покровская, Людмила Гурченко, Елена Соловей, Георгий Тейх, Николай Лавров, Юрий Визбор, Виктор Павлов и др. Драма.

Любовь с первого взгляда. СССР, 1975. Режиссер Резо Эсадзе. Сценарист Эдуард Тополь. Актеры: Вахтанг Панчулидзе, Наталья Юриздицкая, Рамаз Чхиквадзе и др. Комедия.

Меняю собаку на паровоз. СССР, 1975. Режиссер Никита Хубов. Сценаристы: Сергей Михалков, Никита Хубов. Актеры: Дмитрий Шевелев, Татьяна Лаврова, Виктор Сергачёв, Дмитрий Ажнин, Павел Панков, Олег Табаков и др. Комедия.

Порясающий Берендеев. СССР, 1975. Режиссер Игорь Вознесенский. Сценарист Владимир Потоцкий. Актеры: Сергей Образов, Андрей Харыбин, Евгений Евстигнеев, Лилия Журкина, Борис Иванов, Леонид Каневский, Лев Дуров, Алексей Смирнов и др. Комедия.

Сто дней после детства. СССР, 1975. Режиссер Сергей Соловьев. Сценаристы: Александр Александров, Сергей Соловьев. Актеры: Борис Токарев, Татьяна Друбич, Ирина Малышева, Юрий Агилин, Нина Меньшикова, Сергей Шакуров, Арина Алейникова и др. Драма.

Школа господина Мариуса. СССР, 1975. Режиссер Микк Микивер. Сценаристы: Арво Круусемент, Лембит Реммельгас. Актеры: Харри Кырвитс, Антс Эскола, Мария Кленская, Кальё Кийск, Юри Ярвет и др. Драма.

Что с тобой происходит? СССР, 1975. Режиссер Владимир Саруханов. Сценарист Юз Алешковский. Актеры: Вячеслав Баранов, Оля Пономарева, Борис Зайденберг, Данута Столярская, Лилиана Алешникова и др. Драма.

Чужие письма. СССР, 1975. Режиссер Илья Авербах. Сценарист Наталья Рязанцева. Актеры: Ирина Купченко, Светлана Смирнова, Сергей Коваленков, Зинаида Шарко, Олег Янковский, Иван Бортник и др. Драма.

Это мы не проходили. СССР, 1975. Режиссер Илья Фрэз. Сценаристы: Илья Фрэз, Михаил Львовский. Актеры: Наталья Рычагова, Борис Токарев, Андрей Ростоцкий, Татьяна Канаева, Ирина Калиновская, Антонина Максимова, Татьяна Пельтцер, Нина Зоткина, Вера Васильева и др. Драма. 
Эта тревожная зима. СССР, 1975. Режиссер Игорь Николаев. Сценарист Валентина Спирина. Актеры: Александр Копов, Эдуард Марцевич, Елена Костерова и др. Драма.

1976

Все дело в брате. СССР, 1976. Режиссер Валентин Горлов. Сценаристы: Павел Лунгин, Валентин Горлов. Актеры: Роман Мадянов, Юрий Дуванов, Наташа Сеземан, Марина Горлова, Элеонора Шашкова и др. Драма.

Два капитана. СССР, 1976. Режиссер Евгений Карелов. Сценаристы: Евгений Карелов, Вениамин Каверин (автор одноименного романа - В. Каверин). Актеры: Борис Токарев, Серёжа Кудрявцев, Елена Прудникова, Лена Лобкина, Юрий Богатырёв, Николай Гриценко, Ирина Печерникова и др. Драма.

Дневник Карлоса Эспинолы. СССР, 1976. Режиссер и сценарист Валентин Селиванов. Актеры: Хоссе Бельместр, Марина Мухина, Карлос Сохо, Элеонора Шашкова, Вячеслав Шалевич, Людмила Чурсина и др. Драма.

Додумался, поздравляю! СССР, 1976. Режиссер Эдуард Гаврилов. Сценарист Анатолий Усов. Актеры: Алексей Ершов, Наталья Тенищева, Юра Юрьев, Люся Мухина, Роман Мадянов, Галина Польских, Олег Анофриев и др. Драма.

Ключ без права передачи. СССР, 1976. Режиссер Динара Асанова. Сценарист Георгий Полонский. Актеры: Елена Проклова, Алексей Петренко, Лидия ФедосееваШукшина, Любовь Малиновская, Зиновий Гердт, Екатерина Васильева, Олег Хроменков, Анвар Асанов, Марина Левтова, Елена Цыплакова и др. Драма.

Несовершеннолетние. СССР, 1976. Режиссер Владимир Роговой. Сценарист Эдуард Тополь. Актеры: Владимир Летенков, Станислав Жданько, Николай Муравьёв, Леонид Каюров, Павел Николаи, Вера Васильева, Юрий Кузыменков, Юрий Медведев и др. Драма.

Опровержение. СССР, 1976. Режиссер Юрий Кавтарадзе. Сценаристы: Василий Ардаматский, Юрий Кавтарадзе. Актеры: Лилиана Алешникова, Борис Гусаков, Николай Скоробогатов, Пётр Щербаков и др. Драма.

Остров юности. СССР, 1976. Режиссеры: Юлий Слупский, Борис Шиленко. Сценарист Александр Власов. Актеры: Владимир Андреев, Оля Демшевская, Виталий Лобзин и др. Драма.

Подранки. СССР, 1976. Режиссер и сценарист Николай Губенко. Актеры: Юозас Будрайтис, Алексей Черствов, Георгий Бурков, Александр Калягин, Жанна Болотова, Ролан Быков, Николай Губенко, Наталья Гундарева, Евгений Евстигнеев и др. Драма.

Предательница. СССР, 1976. Режиссер Никита Хубов. Сценаристы: Валерий Демин, Людмила Демина, Никита Хубов. Актеры: Лариса Блинова, Георгий Киянцев, Игорь Кучин и др. Драма.

Розыгрыш. СССР, 1976. Режиссер Владимир Меньшов. Сценарист Семён Лунгин. Актеры: Дмитрий Харатьян, Евгения Ханаева, Наталья Вавилова, Андрей Гусев, Евдокия Германова, Олег Табаков, Наталья Фатеева, Зиновий Гердт, Владимир Меньшов, Гарри Бардин и др. Музыкальная драма.

Тимур и его команда. СССР, 1976. Режиссеры: Александр Бланк, Сергей Линков. Сценаристы: Александр Бланк, Сергей Линков, Нина Давыдова (автор повести - А. Гайдар). Актеры: Антон Табаков, Инга Третьякова, Вячеслав Баранов, Лев Идашкин, Леонид Куравлёв, Бруно Фрейндлих, Любовь Соколова, Николай Гринько и др. Драма.

Цветы для Оли. СССР, 1976. Режиссер Радомир Василевский. Сценарист Радий Погодин. Актеры: Анна Надточий, Александр Лихачев, Вадим Шевченко и др. Мелодрама.

1977

Доброта. СССР, 1977. Режиссер Эдуард Гаврилов. Сценаристы: Семен Ласкин, Василий Соловьёв (автор повести «Абсолютный слух» - С.Ласкин). Актеры: Тамара Сёмина, Леонид Неведомский, Николай Константинов, Владимир Звягин, Андрей Гусев, Алина Покровская и др. Драма.

Жили-были в первом классе... СССР, 1977. Режиссер Маргарита Касымова. Сценаристы: Владимир Железников, Алексей Леонтьев (автор повести «Поющий тростник» Г. Галахова). Актеры: Сино Ахмедов, Улугбек Садыков, Женя Бабаев и др. Драма. 
Последняя двойка. СССР, 1977. Режиссер Борис Нащекин. Сценарист И. Витин. Актеры: Александр Ивахин, Евгений Герасимов, Людмила Иванова и др. Драма.

Школьный вальс. СССР, 1977. Режиссер Павел Любимов. Сценарист Анна Родионова.

Актеры: Елена Цыплакова, Сергей Насибов, Евгения Симонова, Наталья Вилькина, Юрий Соломин, Нина Меньшикова и др. Мелодрама.

\section{8}

Баламут. СССР, 1978. Режиссер Владимир Роговой. Сценарист Сергей Бодров (ст.). Актеры: Вадим Андреев, Наталья Казначеева, Николай Денисов, Владимир Шихов, Валентина Клягина и др. Комедия.

Когда я стану великаном. СССР, 1978. Режиссер Инна Туманян. Сценаристы: Инна Туманян, Александр Кузнецов. Актеры: Михаил Ефремов, Наташа Сеземан, Лия Ахеджакова, Инна Ульянова, Марина Шиманская, Олег Ефремов, Владимир Качан и др. Драма.

Последний шанс. СССР, 1978. Режиссер Эдуард Гаврилов. Сценаристы: Ирина Рабкина, Борис Рабкин. Актеры: Андрей Мартынов, Леонид Каюров, Олег Ефремов, Марина Левтова, Андрей Харыбин, Анатолий Кузнецов, Любовь Соколова, Людмила Шагалова, Валентина Ананьина, Наталья Гвоздикова, Александр Кавалеров и др. Драма.

Расписание на послезавтра. СССР, 1978. Режиссер Игорь Добролюбов. Сценарист Нина Фомина. Актеры: Олег Даль, Маргарита Терехова, Тамара Дегтярёва, Александр Леньков, Александр Денисов, Валентин Никулин, Вячеслав Баранов, Юрий Воротницкий, Владимир Солодовников, Ирина Метлицкая, Полина Медведева, Евгений Стеблов, Валентина Титова, Борис Новиков и др. Драма.

Сдается квартира с ребенком. СССР, 1978. Режиссер Виктор Крючков. Сценарист Эдуард Акопов. Актеры: Елена Фетисенко, Александр Копов, Миша Кожекин, Людмила Дьяконова, Павел Винник, Алла Мещерякова, Виталий Соломин, Николай Парфёнов и др. Комедия.

Смилуйся над нами. СССР, 1978. Режиссер Альгирдас Араминас. Актеры: Альгирдас Латенас, Дмитрий Миргородский, Татьяна Майорова и др. Драма.

Уроки французского. СССР, 1978. Режиссер и сценарист Евгений Ташков. Автор одноименного рассказа - Валентин Распутин. Актеры: Михаил Егоров, Татьяна Ташкова, Галина Яцкина, Валентина Талызина, Борис Новиков и др. Драма.

1979

В моей смерти прошу винить Клаву К. СССР, 1979. Режиссеры: Николай Лебедев, Эрнест Ясан. Сценарист Михаил Львовский. Актеры: Надежда БоргесаниГоршкова, Владимир Шевельков, Лена Хопшоносова и др. Мелодрама.

Камертон. СССР, 1979. Режиссер Виллен Новак. Сценарист Леонид Браславский. Актеры: Елена Шанина, Борис Сабуров, Андрей Ташков и др. Драма. Актеры:

Кузнечик. СССР, 1979. Режиссер Борис Григорьев. Сценарист Феликс Миронер.

Людмила Нильская, Николай Иванов, Людмила Аринина, Анатолий Ромашин, Марина Левтова, Вячеслав Баранов и др. Драма.

Мой первый друг. СССР, 1979. Режиссер Яков Базелян. Сценаристы: Ганна Слуцки, Александр Хмелик. Актеры: Егор Грамматиков, Валерий Владинов, Анна Голубева, Ольга Волкова и др. Драма.

Полоска нескошенных диких цветов. СССР, 1979. Режиссер Юрий Ильенко. Сценаристы: Юрий Ильенко, Олесь Гончар. Актеры: Юра Маджула, Алексей Черствов, Регимантас Адомайтис, Людмила Ефименко, Зинаида Славина и др. Драма.

Приключения маленького папы. СССР, 1979. Режиссер Дмитрий Крупко. Сценарист Дмитрий Крупко (автор повести «Когда папа был маленьким» А. Раскин).Актеры: Валентин Юцкевич, Александр Демьяненко, Татьяна Томышева и др. Комедия.

Приключения Электроника. СССР, 1979. Режиссер Константин Бромберг. Сценарист Евгений Велтистов. Актеры: Юрий Торсуев, Владимир Торсуев, Василий Скромный, Оксана Алексеева, Николай Гринько, Елизавета Никищихина, Владимир Басов, 
Николай Караченцов, Евгений Весник, Майя Булгакова и др. Фантастика.

Та сторона, где ветер. СССР, 1979. Режиссер Ваграм Кеворков. Сценарист Владислав Крапивин. Актеры: Алексей Мелехов, Виктор Березин, Денис Скударь, Илья Тихонов и др. Драма.

Ты только не плачь. СССР, 1979. Режиссер Алексей Мороз. Сценаристы: Сергей Иванов, Михаил Герман. Актеры: Лена Середа, Володя Чубарев, Павел Кадочников, Валерия Чайковская и др. Драма.

Я буду ждать. СССР, 1979. Режиссер Виктор Живолуб. Сценарист Анатолий Степанов. Актеры: Николай Ерёменко (мл.), Анна Твеленёва, Ирина Шевчук, Константин Степанков, Рита Гладунко, Юрий Каморный и др. Мелодрама.

1980

Алёша. СССР, 1980. Режиссер Виктор Обухов. Сценарист Анатолий Шайкевич. Актеры: Виталий Юшков, Наталия Флоренская, Эрнст Романов, Геннадий Корольков и др. Драма.

Вам и не снилось... СССР, 1980. Режиссер Илья Фрэз. Сценаристы: Галина Щербакова, Илья Фрэз. Актеры: Татьяна Аксюта, Никита Михайловский, Елена Соловей, Ирина Мирошниченко, Лидия Федосеева-Шукшина, Альберт Филозов, Татьяна Пельтцер, Руфина Нифонтова, Евгений Герасимов, Леонид Филатов и др. Мелодрама.

Неоконченный урок. СССР, 1980. Режиссер Анатолий Тютюнник. Сценарист Виктор Гераскин (автор повести «Когда мы взрослеем»- Н.Зелеранский). Актеры: Валерий Никифоров, Альбина Матвеева, Галина Польских и др. Драма.

Подготовка к экзамену. СССР, 1980. Режиссер Борис Конунов. Сценаристы: Евгений Багиров, Александр Юровский (автор одноименной повести Н. Дементьев). Актеры: Елена Финогеева, Геннадий Скоморохов, Наталья Стриженова, Ион Унгуряну и др. Мелодрама. Галин.

Последний побег. СССР, 1980. Режиссер Леонид Менакер. Сценарист Александр

Актеры: Михаил Ульянов, Алексей Серебряков, Ирина Купченко, Леонид Дьячков, Валерий Гатаев, Евгения Ханаева, Виктор Павлов и др. Драма.

Спасатель. СССР, 1980. Режиссер и сценарист Сергей Соловьев. Актеры: Татьяна Друбич, Василий Мищенко, Сергей Шакуров, Ольга Белявская, Вячеслав Кононенко, Александр Кайдановский и др. Драма.

Тихие троечники. СССР, 1980. Режиссер Вячеслав Никифоров. Сценарист Владимир Потоцкий. Актеры: Дмитрий Андриевский, Сережа Скрибо, Елена Антонюк, Марина Левтова, Евгения Ханаева, Елена Драпеко, Ольга Остроумова, Альберт Филозов и др. Драма.

\section{1}

Все наоборот. СССР, 1981. Режиссеры: Виталий Фетисов, Владимир Грамматиков. Сценарист Павел Лунгин. Актеры: Михаил Ефремов, Ольга Машная, Олег Табаков, Светлана Немоляева, Александр Пашутин и др. Комедия.

Наше призвание. СССР, 1981. Режиссер Геннадий Полока. Сценаристы: Геннадий Полока, Евгений Митько (автор книги Н. Огнев). Актеры: Валерий Золотухин, Павел Кадочников, Василий Мищенко, Георгий Тейх, Игорь Наумов, Ия Саввина, Фёдор Никитин, Валентина Теличкина и др. Драматическая комедия.

Придут страсти-мордасти. СССР, 1981. Режиссер и сценарист Эрнест Ясан. Актеры: Дмитрий Кузьмин, Антон Гранат, Людмила Шевель и др. Драма.

Прощание за чертой. СССР, 1981. Режиссер Карен Геворкян. Сценаристы: Карен Геворкян, Александр Диванян. Актеры: Л. Манукян, А. Миракян, В. Плузян и др. Драма.

Снег на зеленом поле. СССР, 1981. Режиссер Валентин Морозов. Сценарист Эдуард Шим. Актеры: Дима Веселков, Саша Гладкобородов, Оля Дуренкова и др. Драма.

Трудное начало. СССР, 1981. Режиссер Тенгиз Магалашвили. Сценаристы: Эрлом Ахвледиани, Тенгиз Магалашвили. Актеры: Ираклий Хизанишвили, Нани Чиквинидзе, Эдишер Магалашвили и др. Драма.

Что бы ты выбрал? СССР, 1981. Режиссер Динара Асанова. Сценарист Александр 
Кургатников. Актеры: Анвар Асанов, Марина Кривицкая, Настя Никольская, Ярослав Яковлев, Лидия Федосеева-Шукшина, Екатерина Васильева, Елена Соловей и др. Драма.

Кафедра. СССР, 1982. Режиссер Иван Киасашвили. Сценаристы: Ирина Грекова, Семён Лунгин, Марк Розовский (автор одноименной повести - И. Грекова). Актеры: Андрей Попов, Светлана Кузьмина, Ростислав Янковский, Галина Макарова, Елена Степанова, Игорь Ясулович, Елена Антоненко, Александр Кайдановский, Виктор Сергачёв и др. Драма.

\section{2}

Колыбельная для брата. СССР, 1982. Режиссер Виктор Волков. Актеры: Егор Грамматиков, Лена Москаленко, Володя Зотов и др. Драма.

Мы жили по соседству. СССР, 1982. Режиссер и сценарист Николай Лырчиков. Актеры: Жанна Прохоренко, Андрей Мартынов, Антон Голышев и др. Мелодрама.

С тех пор, как мы вместе. СССР, 1982. Режиссер Владимир Григорьев. Сценарист Святослав Тараховский. Актеры: Светлана Смирнова, Андрис Лиелайс, Антонина Шуранова и др. Мелодрама.

4:0 в пользу Танечки. СССР, 1982. Режиссер Радомир Василевский. Сценарист Михаил Дымов. Актеры: Наталия Флоренская, Андрей Мягков, Светлана Немоляева, Евгения Ханаева, Юрий Васильев, Елена Санько, Вацлав Дворжецкий и др. Комедия.

Чужая пятерка. СССР, 1982. режиссер Г. Бзаров. Сценарист В. Малиновская. Актеры: У. Хамраев, В. Ибрагимова, Ф. Реджаметова и др. Драма.

1983

Если верить Лопотухину. СССР, 1983. Режиссер Михаил Козаков. Сценарист Александр Хмелик. Актеры: Григорий Евсеев, Леонид Броневой, Светлана Крючкова, Борислав Брондуков и др. Комедия.

Магия черная и белая. СССР, 1983. Режиссер Наум Бирман. Сценарист Валерий Приёмыхов. Актеры: Павел Плисов, Антон Гранат, Рита Иванова, Александр Леньков и др. Комедия.

Обман. СССР, 1983. Режиссер Николай Раужин. Сценарист Альберт Иванов (автор рассказа. «Любовь октябрёнка Овечкина» Н. Соломко). Актеры: Ольга Дольникова, Вячеслав Невинный, Любовь Германова и др. Мелодрама.

Опасные пустяки. СССР, 1983. Режиссер: Виктор Волков. Актеры: Инна Гомес, Наталья Гусева, Коля Макаров и др. Агитфильм.

Пацаны. СССР, 1983. Режиссер Динара Асанова. Сценарист Юрий Клепиков. Актеры: Валерий Приёмыхов, Андрей Зыков, Сергей Наумов, Евгений Никитин, Олег Хорев, Александр Совков, Ольга Машная и др. Драма.

Плыви, кораблик. СССР, 1983. Режиссер Григорий Аронов. Сценаристы: Сергей Александрович, Григорий Аронов. Актеры: Стефания Станюта, Павлик Шагин, Татьяна Иванова и др. Драма.

Признать виновным. СССР, 1983. Режиссер Игорь Вознесенский. Сценаристы: Владимир Карасев, Юрий Иванов. Актеры: Александр Михайлов, Владимир Шевельков, Игорь Рогачёв, Александр Силин, Марина Яковлева, Вера Сотникова, Ирина Мирошниченко и др. Драма.

Приключения Петрова и Васечкина. СССР, 1983. Режиссер Владимир Алеников. Сценаристы: Владимир Алеников, Валентин Горлов. Актеры: Дмитрий Барков, Егор Дружинин, Инга Ильм и др. Музыкальная комедия.

Талисман. СССР, 1983. Режиссеры: Араик Габриэлян, Вениамин Дорман. Сценарист Виктория Токарева. Актеры: Денис Чурмантеев, Наталья Варлей, Лидия ФедосееваШукшина, Спартак Мишулин, Лия Ахеджакова, Борислав Брондуков, Элеонора Шашкова и др. Комедия.

Уроки на завтра. СCCP, 1983. Режиссер А. Акбарходжаев. Сценарист М. Мухаммад Дост. Актеры: М. Мухаммад Дост, Б. Ихтияров, М. Абзалов и др. Драма. Ремез.

Утро без отметок. СССР, 1983. Режиссер Владимир Мартынов. Сценарист Оскар

Актеры: Кирилл Головко-Серский, Маша Вартикова, Павел Гайдученко и др. Комедия.

Чучело. СCCP, 1983. Режиссер Ролан Быков. Сценаристы: Ролан Быков, Владимир 
Железников. Актеры: Кристина Орбакайте, Юрий Никулин, Елена Санаева, Дмитрий Егоров, Ксения Филиппова и др. Драма.

\section{4}

Благие намерения. СССР, 1984. Режиссер Андрей Бенкендорф. Сценарист и автор одноименной повести Альберт Лиханов. Актеры: Марина Яковлева, Юрий Платонов, Маша Баленко и др. Драма.

Дневник, письмо и первоклассница. СССР, 1984. Режиссер Хабиб Файзиев. Сценарист

Валентина Малиновская. Актеры: Равшан Хамраев, Улугбек Хамраев, Гулнора Пайзиева и др. Драма.

Единица с обманом. СССР, 1984. Режиссер Андрей Праченко. Сценарист Александр Гусельников (автор одноименной повести В. Нестайко). Актеры: Елена Борзунова, Елена Зайцева, Олег Кропот и др. Комедия.

Идущий следом. СССР, 1984. Режиссер Родион Нахапетов. Сценаристы: Родион Нахапетов, Юлий Николин. Актеры: Ивар Калныньш, Николай Гринько, Елена Прудникова, Пётр Глебов, Андрей Смирнов, Вера Глаголева, Владислав Стржельчик, Римма Маркова и др. Драма.

Лидер. СССР, 1984. Режиссер Борис Дуров. Сценарист Даль Орлов. Актеры: Алексей Волков, Александр Стриженов, Екатерина Стриженова, Валентина Карева, Анатолий Опритов, Любовь Стриженова и др. Драма.

Моя маленькая жена. СССР, 1984. Режиссер Раймундас Банионис. Сценарист Римантас Шавялис. Актеры: Элеонора Коризнайте, Саулюс Баландис, Ингеборга Дапкунайте и др. Мелодрама.

Подслушанный разговор. СССР, 1984. Режиссер и сценарист Сергей Потепалов. Актеры: Гия Думбадзе, Алексей Полуян, Ольга Агапова и др. Мелодрама.

Пока не выпал снег. СССР, 1984. Режиссер Игорь Апасян. Сценаристы: Елена Щербиновская, Людмила Абрамова, Игорь Апасян. Актеры: Наталья Сайко, Александр Пороховщиков, Елена Соловей, Евгения Добровольская, Ольга Машная и др. Драма.

Почти ровесники. СССР, 1984. Режиссер Татьяна Пименова. Сценарист Денис Драгунский. Актеры: Михаил Морозов, Елена Новосельская, Юра Жуков и др. Драма.

Сильная личность из 2 «А». СССР, 1984. Режиссер Анатолий Ниточкин. Сценарист Геннадий Мамлин. Актеры: Женя Пивоваров, Екатерина Лычева, Любовь Соколова, Андрей Мартынов, Валентина Теличкина и др. Комедия.

Сладкий сок внутри травы. СССР, 1984. Режиссеры: Аманбек Альпиев, Сергей Бодров (ст.). Сценаристы: Зауреш Ергалиева, Сергей Бодров (ст.). Актеры: Гульшад Омарова, Айгерим Беккулова, Элико Минашвили и др. Мелодрама.

Солнце в кармане. СССР, 1984. Режиссер Эдуард Гаврилов. Сценаристы: Эдуард Гаврилов, Ольга Сидельникова. Актеры: Даша Вишнякова, Вера Ивлева, Мария Скворцова и др. Драма.

Третий в пятом ряду. СCCP, 1984. Режиссер Сергей Олейник. Сценарист Екатерина Маркова (автор одноименной повести А. Алексин). Актеры: Алла Покровская, Александр Продан, Юлия Космачёва и др. Драма.

1985

Валентин и Валентина. СССР, 1985. Режиссер Георгй Натансон. Сценаристы: Георгий Натансон, Михаил Рощин (автор одноименной пьесы - В. Рощин). Актеры: Марина Зудина, Николай Стоцкий, Татьяна Доронина, Нина Русланова, Зинаида Дехтярёва, Борис Щербаков, Лариса Удовиченко, Люсьена Овчинникова и др. Мелодрама.

Зловредное воскресенье. СССР, 1985. Режиссер Владимир Мартынов. Сценарист Оскар Ремез. Актеры: Павел Гайдученко, Михаил Пуговкин, Вера Васильева, Валентина Талызина, Марина Дюжева, Раиса Рязанова, Георгий Штиль, Борислав Брондуков, Евгений Герасимов, Марина Яковлева и др. Комедия. Лайус

Игры для детей школьного возраста. СССР, 1985. Режиссеры: Арво Ихо, Лейда

Сценарист Марина Шептунова (автор повести «Приемная мать» - С. Раннамаa). 
Актеры: Моника Ярв, Хендрик Тоомпере и др. Драма.

Как молоды мы были. СССР, 1985. Режиссер и сценарист М. Беликов. Актеры: Т. Денисенко, Е. Шкурпело, А. Пашутин и др. Мелодрама.

Мужчины есть мужчины. СССР, 1985. Режиссер и сценарист Алексей Мороз. Актеры: Петя Митрюхин, Виталий Шевцов, Сергей Хусаинов и др. Комедия.

Непохожая. СССР, 1985. Режиссеры: Владимир Алеников, Мария Муат. Сценарист Екатерина Маркова (автор повести «Родео Лиды Карякиной» - Людмила Сабинина). Актеры: Ольга Толстецкая, Клара Лучко, Евгения Ханаева, Александра Турган, Всеволод Абдулов, Александра Захарова, Юрий Чернов, Александр Пашутин и др. Драма.

Осторожно - Василёк! СССР, 1985. Режиссер Эдуард Гаврилов. Сценарист Ольга Сидельникова. Актеры: Илья Тюрин, Георгий Бурков, Олег Ефремов и др. Комедия.

С нами не соскучишься. СССР, 1985. Режиссер Антонина Зиновьева. Сценарист Сергей Иванов. Актеры: Павел Суворов, Анастасия Фатеева, Ксения Кутепова, Полина Кутепова, Геннадий Сайфулин и др. Драма.

\section{6-1991}

\section{6}

Белая лошадь - горе не моё. СССР, 1986. Режиссер: Виктор Спиридонов. Актеры: Сергей Балабанов, Леонид Марков, Александр Пороховщиков и др. Драма.

Была не была. СССР, 1986. Режиссер Валерий Федосов. Сценаристы: Александр Чумак, Юрий Перов. Актеры: Григорий Катаев, Тина Лаптева, Алексей Жарков, Валентина Теличкина, Лариса Белогурова и др. Драма.

За явным преимуществом. СССР, 1986. Режиссер Владимир Саруханов. Сценарист Анатолий Мадорский. Актеры: Олег Старосацкий, Нина Саруханова, Владимир Борисов, Игорь Буланцев, Паул Буткевич, Армен Джигарханян и др. Драма.

Здравствуйте, Гульнора Рахимовна! СССР, 1986. Режиссер Абдурахим Кудусов. Сценаристы: Валентина Малиновская, В. Федоров. Актеры: Тамара Яндиева, Бахтиер Фидоев, Ирбек Алиев и др. Драма.

Листопад в пору лета. СССР, 1986. Режиссер Тофик Исмайлов. Сценарист Асим Джалилов. Актеры: Сиявуш Аслан, Наджиба Гусейнова, Фирангиз Шарифова и др. Драма.

Малявкин и компания. СССР, 1986. Режиссер Юрий Кузьменко. Сценарист Юрий Яковлев. Актеры: Сергей Савостьянов, Максим Гапонов, Ася Власенко и др. Комедия.

Очень страшная история. СССР, 1986. Режиссер Никита Хубов. В ролях: Андрюша Козлов, Толя Юртаев, Вера Панасенкова, Людмила Артемьева, Станислав Садальский и др. Детектив.

Плюмбум, или Опасная игра. СССР, 1986. Режиссер Вадим Абдрашитов. Сценарист Александр Миндадзе. Актеры: Антон Андросов, Елена Дмитриева, Елена Яковлева, Зоя Лирова, Александр Феклистов, Владимир Стеклов, Александр Пашутин и др. Драма.

Әкзамен на директора. СССР, 1986. Режиссер Александр Ефремов. Сценаристы: Владимир Бутромеев, Евгений Митько. Актеры: Сергей Шкаликов, Михаил Глузский, Юрий Казючиц и др. Драма.

Я - вожатый форпоста. СССР, 1986. Режиссер Геннадий Полока. Сценаристы: Евгений Митько, Геннадий Полока (автор книги Н. Огнев). Актеры: Павел Кадочников, Василий Мищенко, Валерий Золотухин, Ия Саввина и др. Драма.

\section{7}

Дом с привидениями. СССР, 1987. Режиссер Ефим Гальперин. Сценарист Семён Лунгин. Актеры: Катя Цуканова, Виктория Гаврилова, Ярослав Лисоволик, Сергей Домнин и др. Драма.

Забавы молодых. СССР, 1987. Режиссер Евгений Герасимов. Сценарист Виктор Мережко. Актеры: Станислав Любшин, Марина Зудина, Нина Русланова, Валентина Теличкина, Николай Парфёнов, Виктор Павлов, Вячеслав Невинный, Алексей Серебряков, Владимир Качан, Ирина Климова и др. Драма.

Завтра была война. СССР, 1987. Режиссер Юрий Кара. Сценарист и автор 
одноименнйо повести Борис Васильев. Актеры: Сергей Никоненко, Нина Русланова, Вера Алентова, Ирина Чериченко, Наталья Негода, Юлия Тархова, Владимир Заманский и др. Драма.

Мы - ваши дети. СССР, 1987. Режиссер Ольгерд Воронцов. Сценаристы: Геннадий Никитин, Ольга Пыжова (авторы пьесы «Иван» Г. Никитин и О. Пыжова). Актеры: Галина Польских, Леонид Куравлёв, Валерий Малинин, Валерий Баринов, Сергей Сазонтьев и др. Драма.

Пощечина, которой не было. СССР, 1987. Режиссер Игорь Шатров. Сценаристы: Рустам Ибрагимбеков, Виктор Багдасаров. Актеры: Андрей Болтнев, Людмила Соловьёва, Владимир Стеклов, Ольга Рачинская, Вадим Любшин, Игорь Кашинцев, Ксения Стриж, Александр Стриженов и др. Драма.

Соблазн. СССР, 1987. Режиссер Вячеслав Сорокин. Сценаристы: Юрий Клепиков, Валерий Стародубцев. Актеры: Алиса Зыкина, Наталия Сорокина, Сергей Лучников, Елена Руфанова и др. Драма.

Тихоня. СССР, 1987. Режиссер Ю. Азимов. Сценаристы: П. Луцик, А. Саморядов. Актеры: Г. Аминова, А. Каримова, А. Мухитдинов и др. Драма.

Шантажист. СССР, 1987. Режиссер Валерий Курыкин. Сценарист Эдуард Володарский.

Актеры: Михаил Ефремов, Андрей Тихомирнов, Александр Ширвиндт, Марина Старых, Нина Гомиашвили, Леонид Куравлёв, Валентина Титова, Сергей Гармаш и др. Драма.

1988

Воля Вселенной. СССР, 1988. Режиссёр Дмитрий Михлеев. Актеры: Вячеслав Илющенко, Наталья Гусева, Андрей Бабошкин, Виктор Ильичёв и др. Мелодрама.

Дорогая Елена Сергеевна. СССР, 1988. Режиссер Эльдар Рязанов. Сценаристы: Людмила Разумовская, Эльдар Рязанов (автор одноименной пьесы - Л. Разумовская). Актеры: Марина Неёлова, Наталья Щукина, Фёдор Дунаевский, Дмитрий Марьянов, Андрей Тихомирнов. Драма.

Куколка. СССР, 1988. Режиссер Исаак Фридберг. Сценарист Игорь Агеев. Актеры: Светлана Засыпкина, Ирина Метлицкая, Владимир Меньшов, Наталья Назарова и др. Драма.

На окраине, где-то в городе... СССР, 1988. Режиссер Валерий Пендраковский. Сценарист Владислав Романов. Актеры: Александр Ларионов, Андрей Мананников, Антон Шереметьев и др. Драма.

Публикация. СССР, 1988. Режиссер Виктор Волков. Сценарист Юрий Коротков. Актеры: Людмила Аринина, Лариса Шахворостова, Владислав Дашевский, Никита Гурьев и др. Драма.

Пусть я умру, господи... СССР, 1988. Режиссер Борис Григорьев. Сценарист Галина Щербакова. Актеры: Галина Польских, Иван Лапиков, Елена Морозова, Игорь Ледогоров, Лидия Федосеева-Шукшина, Леонид Куравлёв и др. Драма.

Работа над ошибками. СССР, 1988. Режиссер Андрей Бенкендорф. Сценарист Владимир Холодов (автор одноименной повести - Ю. Поляков). Актеры: Евгений Князев, Оксана Дроздова, Елена Чухалёнок и др. Драма.

Стукач. СССР, 1988. Режиссер и сценарист Николай Лырчиков. Актеры: Артем Тынкасов, Александр Феклистов, Аркадий Левин, Виктор Павлюченков, Владимир Стеклов, Игорь Дмитриев и др. Драма.

Шут. СССР, 1988. Режиссер Андрей Эшпай. Сценарист и автор одноименной повести Юрий Вяземский. Актеры: Дмитрий Весенский, Мария Маевская, Игорь Костолевский и др. Драма.

Щенок. СССР, 1988. Режиссер Александр Гришин. Сценарист Юрий Щекочихин. Актеры: Сергей Роженцев, Федор Гаврилов, Владимир Шевельков, Вениамин Смехов, Всеволод Сафонов и др. Драма.

Авария - дочь мента. СССР, 1989. Режиссёр Михаил Туманишвили. Сценарист 
Юрий Коротков. Актеры: Оксана Арбузова, Владимир Ильин, Анастасия Вознесенская, Николай Пастухов, Борис Романов, Игорь Нефёдов и др. Драма.

Астенический синдром. СССР, 1989. Режиссер Кира Муратова. Сценаристы: Кира Муратова, Сергей Попов, Александр Черных. Актеры: Ольга Антонова, Сергей Попов, Галина Захурдаева, Наталья Бузько, Александра Свенская, Павел Полищук (II), Наталья Раллева, Галина Касперович, Виктор Аристов и др. Драма.

Казенный дом. СССР, 1989. Режиссёр Альберт Мкртчян. Автор сценария Михаил Кончакивский. Актеры: Галина Польских, Нина Русланова, Алёша Сергиевский, Алёша Колесов, Павел Гайдученко и др. Драма.

Князь Удача Андреевич. СССР, 1989. Режиссер Геннадий Байсак. Сценарист Валерий Приемыхов. Актеры: Евгений Пивоваров, Дмитрий Головин, Светлана Крючкова, Виктор Павлов, Армен Джигарханян, Станислав Садальский и др. Детектив.

Мир в другом измерении. СССР, 1989. Режиссеры: Михаил Кончакивский, Альберт Мкртчян. Сценаристы: Михаил Кончакивский, Елена Ласкарева. Актеры: Алеша Колесов, Иван Бортник, Владимир Кукушкин, Александра Колкунова, Ирина Мирошниченко, Нина Русланова, Галина Польских, Владимир Ильин, Владимир Самойлов и др. Драма.

Поджигатели. СССР, 1989. Режиссер Александр Сурин. Сценарист Алла Криницына. Актеры: Наталья Федотова, Елена Сидорук, Лариса Осипова, Елена Крючкова, Виктория Князева и др. Драма.

1990

Сообщница. СССР, 1990. Режиссер Владимир Опенышев. Сценарист Нина Филиппова. Актеры: Юлия Тархова, Александр Баширов, Сергей Быстрицкий и др. Драма.

СЭР. СССР, 1989. Режиссер и сценарист Сергей Бодров (ст.). Актеры: Володя Козырев, Светлана Гайтан, Александр Буреев и др. Драма.

Это было у моря. СССР, 1989. Режиссер Аян Шахмалиева. Сценарист Елена Лобачевская. Актеры: Нина Русланова, Светлана Крючкова, Ника Турбина, Катя Политова и др. Драма.

Сделано в СССР. СССР, 1990. Режиссеры: Владимир Шамшурин, Святослав Тараховский. Сценарист Святослав Тараховский. Актеры: Армен Джигарханян, Оксана Арбузова, Кирилл Белевич, Александра Фомичёва, Алла Клюка, Вера Панасенкова, Леонид Куравлёв, Эдуард Марцевич, Валентина Теличкина и др. Драма.

Хомо новус. СССР, 1990. Режиссер Пал Эрдёш. Сценарист Зоя Кудря. Актеры: Ирина Купченко, Георгий Тараторкин, Анна Баженова, Римма Маркова и др. Драма.

1991

Милый Эп. СССР, 1991. Режиссер Олег Фомин. Сценарист и автор одноименной повести Геннадий Михасенко. Актеры: Михаил Палатник, Инна Хрулёва, Игорь Юраш, Александр Стриженов, Ирина Рябцева и др. Драма.

Окно. СССР, 1991. Режиссеры Гасан Аблуч, Энвер Аблуч. Сценарист Иси Мелик-заде. Актеры: Ильхам Бабаев, Валех Керимов, Яшар Нури и др. Драма.

\section{Фильмография российских фильмов (включая сериалы) о школе и вузе}

1992-2017

1993

Равноправие. Россия, 1993. Режиссер Сергей Багиров. Сценарист Александр Детков. Актеры: Наталья Карпунина и др. Драма.

Рыпкина любовь. Россия, 1993. Режиссёр: Сергей Багиров. В ролях: Костя Курас, Олег Абрамов, Павел Евсеев, Оксана Шевченко и др. Комедия.

АБВГД Ltd Россия, 1992-1994. Сценаристы: Михаил Васильев, Константин 
Наумочкин, Олег Осипов, Алексей Овчинников. Актеры:Антон Табаков, Роман Рябов, Авангард Леонтьев, Мария Порошина, Ярослав Бойко, Гоша Куценко и др. Комедия.

1995

Какая чудная игра. Россия, 1995. Режиссер и сценарист Пётр Тодоровский. Актеры: Андрей Ильин, Геннадий Назаров, Денис Константинов, Геннадий Митник, Елена Яковлева, Лариса Удовиченко, Николай Бурляев, Юрий Кузнецов, Алексей Золотницкий, Дмитрий Марьянов, Мария Шукшина и др. Драма.

1996

Әкзамены. Россия, 1996. Режиссер и сценарист Дмитрий Панченко. Актеры: Георгий Предвечнов, Георгий Бутусов, Виталий Бурятинский и др. Драма.

1997

Американка. Россия, 1997. Режиссер Дмитрий Месхиев. Сценарист Юрий Коротков. Актеры: Сергей Васильев, Наталья Данилова, Нина Усатова, Виктор Бычков, Юрий Кузнецов, Алиса Гребенщикова и др. Мелодрама.

Змеиный источник. Россия, 1997. Режиссер и сценарист Николай Лебедев. Актеры: Екатерина Гусева, Ольга Остроумова, Евгений Миронов и др. Триллер.

2000

Нежный возраст. Россия, 2ооо. Режиссер Сергей Соловьев. Сценаристы: Дмитрий Соловьев, Сергей Соловьев. Актеры: Дмитрий Соловьев, Елена Камаева, Ольга Сидорова, Людмила Савельева, Кирилл Лавров, Сергей Гармаш, Андрей Панин, Валентин Гафт и др. Драма.

2001

Московские окна. Россия, 2о01. Режиссер Александр Аравин. Сценаристы: Константин Наумочкин, Алексей Каранович, Игорь Осипов, Алексей Овчинников, Сергей Кобцев, Алексей Поярков, Владимир Неклюдов, Дмитрий Руковишников, Владимир Смирных. Актеры: Анна Арланова, Марина Могилевская, Игорь Бочкин, Елена Аминова, Ксения Алфёрова, Илья Древнов, Николай Чиндяйкин, Елена Финогеева, Игорь Петренко и др. Мелодрама.

Общага. Россия, 20о1. Режиссер Борис Берзнер. Актеры: Владимир Гусев (II), Наталья Карпунина, Юрий Круглов, Максим Лагашкин и др. Комедия.

2002

Займемся любовью. Россия, 2о02. Режиссер Денис Евстигнеев. Сценарист Ариф Алиев. Актеры: Кирилл Малов, Евгений Цыганов, Ульяна Лукина, Андрей Новиков, Иван Кокорин и др. Драма.

Королева красоты, или Очень трудное детство. Россия, 20о2. Режиссеры: Игорь Ахмедов, Борис Чертков. Сценарист Игорь Ахмедов. Актеры: Женя Горбунов, Дарья Сазонова, Александр Королёв, Александр Белявский, Елена Кондулайнен и др. Комедия.

Пер-р-р-вокурсница. Россия, 2оо2. Режиссер и сценарист Юрий Рогозин. Актеры: Мария Шалаева, Дмитрий Шевченко, Юрий Данильченко и др. Комедия.

Театральная академия. Россия, 2002. Режиссеры: Александр Замятин, Вадим Шмелев. Сценаристы: Александр Бачило, Родион Белецкий, Дмитрий Курилов, Юрий Солодов, Вадим Шмелев. Актеры: Денис Никифоров, Ольга Битюцкая, Михаил Богдасаров, Игорь Верник, Эммануил Виторган и др. Комедия.

2003

Весёлая компания. Россия, 2о03. Режиссер Владимир Тихий. Сценаристы: Олег Зима, Георгий Конн, Александра Смилянская, Армен Ватьян. Актеры: Олег Мосалев, Евгений Сиротин, Артём Мазунов, Екатерина Лыкова, Эммануил Виторган, Александр Лыков и др. Комедия.

Простые истины. Россия, 1999-2003. Режиссеры: Вадим Шмелев, Евгений 
Старков, Александр Замятин, Юрий Беленький. Сценаристы: Юрий Беленький, Марк Левин, Вадим Шмелев и др. Актеры: Борис Невзоров, Елена Фатюшина, Наталья Чернявская, Антонина Венедиктова, Анна Исайкина, Ольга Будина и др. Драма.

2004

Кадеты. Россия, 20о4. Режиссер Сергей Артимович. Сценарист Игорь Евсюков. Актеры: Александр Головин, Аристарх Венес, Алексей Мерзлов и др. Драма.

Курсанты. Россия, 2004. Режиссер Андрей Кавун. Сценарист Зоя Кудря. Актеры: Андрей Чадов, Иван Стебунов, Александр Голубев, Алексей Горбунов, Елена Ксенофонтова, Владимир Вдовиченков, Игорь Петренко, Андрей Мерзликин и др. Драма.

Ночь светла. Россия - Украина, 2004. Режиссер Роман Балаян. Сценаристы: Рустам Ибрагимбеков, Роман Балаян. Актеры: Андрей Кузичёв, Алексей Панин, Ольга Сутулова, Ирина Купченко, Владимир Гостюхин и др. Мелодрама.

Вовочка. Россия, 2ооо-20о4. Режиссер и сценарист Андрей Максимков. Актеры: Игорь Качанов, Виктория Корхина, Вадим Гущин, Татьяна Иванова и др. Комедия.

2005

ОБЖ. Россия, 2000-2005. Режиссеры: Антон Азаров, Максим Демченко, Максим Кубринский, Алексей Волынский, Антон Духовской, Полина Бахаревская, Павел Симонов, Дмитрий Петрушков. Сценаристы: Антон Зинченко, Вячеслав Лейкин, Антон Духовской, Татьяна Григорченкова, Иван Милов, Сергей Дмитриев. Актеры: Антон Азаров, Анна Виноградова, Леандра Кудряшова и др. Комедия.

Студенты-1 Россия, 2005. Режиссер Ольга Перуновская. Сценаристы: Вячеслав Дусмухаметов, Виталий Коломиец и др. Актеры: Евгений Кулаков, Сергей Рудзевич, Алексей Янин, Дарья Лузина, Юрий Кузнецов, Владимир Стержаков, Дмитрий Марьянов и др. Комедия.

Тронутые. Россия, 2о05. Режиссер Анатолий Газиев. Сценаристы: Анатолий Газиев, Дмитрий Заболотских. Актеры: Дмитрий Паламарчук, Валентин Захаров, Виталий Исаков, Сергей Барковский и др. Комедия.

2006

Большие девочки. Россия, 2оо6. Режиссеры: Александр Назаров (II), Роман Самгин, Эдуард Ливнев. Сценаристы: Ольга Данилова, Сергей Борзунов, Вадим Голованов, Константин Наумочкин, Иван Филиппов, Алексей Гордовский, Роман Романов (III), Михаил Васильев (II), Наталья Заякина. Актеры: Ольга Остроумова, Валентина Теличкина, Галина Петрова и др. Комедия.

Студенты-2. Россия, 2оо6. Режиссер Ольга Перуновская. Сценаристы: Роман Романов, Алекс Легат, Василий Иванов и др. Актеры: Ивар Калныньш, Владимир Стержаков, Михаил Мамаев и др. Комедия.

Студенты International. Россия, 2о06. Режиссер Ольга Перуновская. Сценаристы: Виталий Шляппо, Вячеслав Дусмухаметов, Алексей Троцюк и др. Актеры: Евгений Кулаков, Евгения Волкова, Алексей Лонгин, Юлия Зимина, Александр Пальчиков, Валерий Золотухин, Александр Панкратов-Чёрный, Владимир Стержаков, Эвелина Блёданс и др. Комедия.

\section{7}

Исчезнувшая империя (Любовь в СССР). Россия, 20о7. Режиссер Карен Шахназаров. Сценаристы: Сергей Рокотов, Евгений Никишов. Актеры: Александр Ляпин, Лидия Милюзина, Егор Барановский, Иван Купреенко, Армен Джигарханян, Ольга Тумайкина, Владимир Ильин и др. Драма.

Кадетство. Россия, 2006-2007. Режиссеры: Сергей Арланов, Валентин Козловский, Павел Игнатов и др. Сценаристы: Леонид Купридо, Александр Булынко, Сергей Олехник и др. Актеры: Александр Головин, Борис Корчевников, Иван Добронравов и др. Комедия.

Потапов, к доске! Россия, 2007. Режиссер Александр Орлов. Сценаристы: Тамара Крюкова, Александр Орлов, Сергей Тарасов. Актеры: Александр Олейников, Виталий Кулаков, Мария Фомина, Валерия Хардина, Лия Ахеджакова и др. Комедия. 
Своя команда. Россия, 2о07. Режиссеры: Дмитрий Панченко, Виктория Орлова, Эдуард Ливнев. Сценаристы: Кирилл Керзок, Дмитрий Щербаков, Елена Имамова, Дмитрий Курилов, Татьяна Малахова, Елена Романенко, Михаил Щедринский, Михаил Беленький, Татьяна Глущенко, Мария Крашенинникова. Актеры: Вячеслав Кулаков, Анастасия Шеховцова, Ирина Цывина и др. Драма.

Учитель в законе. Россия, 2007. Режиссер Александр Мохов. Сценаристы: Алексей Подосенов, Александр Мохов. Актеры: Юрий Беляев, Наталия Вдовина, Кристина Бабушкина и др. Драма.

Школа № 1. Россия, 2007. Режиссеры: Кирилл Белевич, Гюзель Султанова. Сценарист

Елена Воробей. Актеры: Артём Крестников, Сергей Назаров, Мария Костикова, Янина Студилина, Лана Щербакова и др. Драматическая комедия.

\section{8}

Взрослая жизнь девчонки Полины Субботиной. Россия, 20о8. Режиссер Александр Сурин. Сценарист Алла Криницына. Актеры: Любовь Тихомирова, Елизавета Арзамасова, Алексей Кравченко и др. Драма.

Взрослые игры. Россия, 2оо8. Режиссеры: Юрий Ильин, Юлия Морева, Юрий Дружинин. Сценаристы: Елена Ласкарева, Алена Головаш, Анастасия Волкова, Инна Вознюк, Юлия Миланович, Елена Медведева. Актеры: Мария Климова, Степан Старчиков, Екатерина Кабак, Олег Морозов и др. Мелодрама.

Все умрут, а я останусь. Россия, 2008. Режиссер Валерия Гай Германика. Сценаристы: Александр Родионов, Юрий Клавдиев. Актеры: Полина Филоненко, Агния Кузнецова, Ольга Шувалова, Юлия Александрова, Донатас Грудович и др. Драма.

Приколы на переменке. Россия, 2007-2008. Режиссеры: Виктор Рудниченко, Игорь Широков. Сценаристы: Яна Тюльпанова, Игорь Брусенцев. Актеры: Глеб Шевчук, Василий Ракша, Владислав Демидов, Джеймс Бэглоу и др. Комедия.

Розыгрыш. Россия, 20о8. Режиссер Андрей Кудиненко. Сценаристы: Александр Качан, Андрей Житков. Актеры: Юрий Кузнецов, Ирина Купченко, Дмитрий Дюжев, Дмитрий Харатьян, Евдокия Германова и др. Комедия.

Стиляги. Россия, 2о08. Режиссер Валерий Тодоровский. Сценарист Юрий Коротков. Актеры: Антон Шагин, Оксана Акиньшина, Евгения Брик, Максим Матвеев, Екатерина Вилкова, Сергей Гармаш, Олег Янковский, Ирина Розанова, Леонид Ярмольник, Алексей Горбунов и др. Музыкальная драма.

Юленька. Россия, 2оо8. Режиссер Александр Стриженов. Сценаристы: Андрей Курейчик, Григорий Подземельный, Валентин Спиридонов. Актеры: Дарья Балабанова, Марат Башаров, Оксана Лаврентьева, Александра Дыхне, Ирина Купченко и др. Мистический триллер.

\section{9}

Барвиха. Россия, 2009. Режиссер Евгений Лаврентьев. Сценаристы: Шура Никитин, Александр Чалдранян, Илья Артибилов и др. Актеры: Лянка Грыу, Марина Орлова, Анна Михайловская, Анна Хилькевич, Елена Меркулова и др. Драма.

Крыша. Россия, 20о9. Режиссер Борис Грачевский. Сценаристы: Ирина Бурденкова, Борис Грачевский. Актеры: Софья Ардова, Мария Белова, Анфиса Черных, Мария Шукшина, Валерий Гаркалин и др. Драма.

Чучуло-2. Россия, 2009. Режиссер Сергей Кузнецов. Сценарист Галина Арбузова (автор повести «Чучело 2, или Игра мотыльков» - В. Железников). Актеры: Елизавета Бирюкова, Василий Ракша, Полина Дядюх, Алёна Бабенко, Алексей Булдаков, Владислав Ветров и др. Драма.

\section{0}

Детям до 16... Россия, 2о1о. Режиссер Андрей Кавун. Актеры: Лянка Грыу, Анна Старшенбаум, Павел Прилучный, Дмитрий Кубасов, Родион Долгирев, Алексей Горбунов, Ирина Мерцалова, Алексей Шевченков, Ольга Хохлова, Валерий Тодоровский и др. Мелодрама. 
Кремлёвские курсанты. Россия, 2009-2010. Режиссеры: Валентин Козловский, Дмитрий Чирков. Сценаристы: Леонид Купридо, Андрей Чивурин, Александр Кушнаренко, Валентин Иванов и др. Актеры: Денис Береснев, Павел Бессонов, Аристарх Венес и др. Драма.

Старшеклассники. Россия, 2006-2010. Режиссеры: Ядвига Закржевская, Петр Смирнов, Павел Симонов, Татьяна Симонова, Галина Муртазина, Каролина Кубринская, Полина Бахаревская, Валентина Мозолькова, Денис Шибаев, Михаил Смирнов, Олег Тищенко. Сценаристы: Петр Смирнов, Мария Ошмянская, Антон Зинченко, Петр Внуков, Анна Кумачева, Иван Милов, Александра Лусникова, Светлана Сивак, Дамир Салимзянов, Михаил Годин. Актеры: Артём Анчуков, Полина Бахаревская, Александр Бахаревский, Наталья Бахматова и др. Драма.

Ранетки. Россия, 2008-2010. Режиссеры: Сергей Арланов, Валентин Козловский, Карен Захаров, Олег Смольников, Андрей Головков. Сценаристы: Татиана Донская, Ольга Шевченко, Наталья Назарова и др. Актеры: Анна Руднева, Наталья Мильниченко, Евгения Огурцова, Валерия Козлова и др. Музыкальная комедия.

Школа. Россия, 2о1о. Режиссеры: Валерия Гай Германика, Руслан Маликов, Наталия Мещанинова. Сценаристы: Наталья Ворожбит, Нелли Высоцкая, Вячеслав Дурненков, Юрий Клавдиев, Иван Угаров, Ольга Ларионова. Актеры: Алексей Литвиненко, Валентина Лукащук, Анна Шепелева, Наталья Терешкова, Игорь Огурцов, Анатолий Семёнов, Елена Папанова, Александра Ребенок, Наталья Сапецкая и др. Драма.

2011

Белая ворона. Россия, 2о11. Режиссер Сергей Быстрицкий. Сценарист Альжбета Горицвет. Актеры: Глафира Тарханова, Иван Жидков, Александр Лойе и др. Мелодрама.

Золотые. (Барвиха-2). Россия, 2011. Режиссеры: Михаил Соловьёв, Владислав Каптур. Сценаристы: Елена Любарская, Григорий Зельцер. Актеры: Лянка Грыу, Наталья Бардо, Марина Орлова, Анна Михайловская, Андрей Дементьев, Артём Волков, Равшана Куркова, Анна Хилькевич, Елена Меркулова и др. Драма.

Папины дочки. Россия, 2007-2011. Режиссеры: Сергей Алдонин, Ирина Васильева (II), Александр Жигалкин, Валентин Козловский, Эдуард Радзюкевич, Иван Агапов, Олег Смольников, Карен Захаров. Сценаристы: Вячеслав Дусмухаметов, Алексей Троцюк, Виталий Шляппо, Илья Полежайкин, Андрей Дерьков, Александр Гаврильчик, Аскар Бисембин, Денис Хорошун. Актеры: Андрей Леонов, Ольга Волкова, Мирослава Карпович, Анастасия Сиваева, Елизавета Арзамасова и др. Комедия.

Универ. Россия, 20о8-2011. Режиссеры: Пётр Точилин, Иван Китаев, Роман Самгин, Жанна Кадникова. Сценаристы: Вячеслав Дусмухаметов, Семён Слепаков, Илья Полежайкин, Максим Пешков и др. Актеры: Андрей Гайдулян, Валентина Рубцова, Виталий Гогунский, Мария Кожевникова и др. Комедия.

Институт благородных девиц. Россия, 2010-2011. Режиссеры: Леонид Белозорович, Сергей Данелян, Юрий Попович, Ольга Грекова, Сахат Дурсунов, Валерий Рожко, Александр Зеленков. Сценаристы: Юрий Беленький, Елена Ласкарева, Анастасия Волкова, Сергей Кушнир и др. Актеры: Алиса Сапегина, Александр Арсентьев, Иван Колесников, Ксения Хаирова и др. Драма.

Физика или химия. Россия, 2011. Режиссер Рамиль Сабитов. Сценарист Василий Павлов. Актеры: Любовь Германова, Александр Смирнов, Виктория Полторак, Мария Викторова, Анна Невская и др. Мелодрама.

2012

День учителя. Россия, 2012. Режиссер и сценарист Сергей Мокрицкий. Актеры: Анатолий Кот, Светлана Немоляева, Ирина Рахманова, Людмила Титова и др. Комедия.

Закрытая школа. Россия, 2011-2012. Режиссёры: Олег Асадулин, Константин Статский, Антон Новосельцев, Константин Максимов, Марк Горобец, Андрей Записов, Александр Зеленков, Сергей Пищиков. Сценаристы: Алла Максименко, Лусинэ Мартиросян, Оксана Васина и др. Актеры: Антон Хабаров, Татьяна Васильева, Павел Прилучный, Алексей Коряков и др. Мистический триллер.

После школы. Россия-Эстония, 2012. Режиссеры: Андрей Болтенко, Владимир 
Пресняков, Олег Пресняков. Сценаристы: Владимир Пресняков, Олег Пресняков. Актеры:

Сергей Шакуров, Михаил Пореченков, Михаил Трухин, Ксения Раппопорт, Александр Гордон, Анна Михалкова и др. Музыкальная комедия.

Частное пионерское. Россия, 2012. Режиссер Александр Карпиловский. Сценаристы: Алексей Бородачёв, Александр Карпиловский, Татьяна Мирошник. Актеры: Семён Трескунов, Егор Клинаев, Анфиса Вистингаузен, Юлия Рутберг, Светлана Иванова, Владимир Зайцев, Ирина Линдт, Раиса Рязанова, Роман Мадянов и др. Драматическая комедия.

\section{3}

Географ глобус пропил. Россия, 2013. Режиссер Александр Велединский. Сценаристы: Александр Велединский, Валерий Тодоровский, Рауф Кубаев (автор одноименного романа - Алексей Иванов). Актеры: Константин Хабенский, Елена Лядова, Александр Робак, Евгения Брик, Анна Уколова, Агриппина Стеклова и др. Драма.

И шарик вернётся. Россия, 2013. Режиссер Валерий Девятилов. Сценаристы: Анна Аносова, Лариса Леоненко. Актеры: Татьяна Космачёва, Екатерина Травова, Полина Филоненко и др. Мелодрама.

Тайны института благородных девиц. Россия, 2013. Режиссеры: Сергей Данелян, Сахат Дурсунов, Александр И. Строев, Бата Недич. Сценаристы: Михаил Беленький, Юрий Беленький, Виталий Полосухин, Сергей Кушнир и др. Актеры: Алиса Сапегина, Алёна Созинова, Полина Беленькая и др. Драма.

Универ: день открытых дверей. Россия, 2013. Режиссер Роман Новиков. Актеры: Анна Кузина, Роман Петренко, Александр Дулерайн, Арарат Кещян, Илья Полежайкин, Юлия Галиченко и др. Комедия.

Учитель в законе. Возвращение. Россия, 2013. Режиссеры: Сергей Виноградов, Рустам Уразаев. Сценаристы: Василий Игерин, Андрей Тартаков. Актеры: Юрий Беляев, Сергей Векслер, Наталия Антонова, Олеся Судзиловская, Владимир Стеклов и др. Драма.

Цена любви. Россия, 2013. Режиссер Александр Хван. Сценарист Мария Никитина. Актеры: Анна Невская, Юрий Батурин, Анастасия Матвеева и др. Мелодрама.

\section{4}

Анжелика. Россия, 2014. Режиссеры: Радда Новикова, Антон Федотов, Валерия Ивановская, Антон Маслов. Сценаристы: Ирина Журавлёва, Денис Остапчук, Денис Ворочай и др. Актеры: Анжелика Каширина, Ксения Теплова, Мария Баева, Любовь Толкалина и др. Комедия.

Выпускной. Россия, 2014. Режиссер Всеволод Бродский. Сценаристы: Александр Незлобин, Сергей Светлаков, Илья Бурец, Дмитрий Нелидов, Тимофей Зайцев. Актеры: Виктор Грудев, Кристина Исайкина, Ольга Хохлова, Сергей Бурунов и др. Комедия.

Дневник мамы первоклассника. Россия, 2014. Режиссер Андрей Силкин. Сценарист Мария Зверева (автор повести - М. Трауб). Актеры: Светлана Ходченкова, Дима Полунин, Дмитрий Ендальцев и др. Мелодрама.

Класс коррекции. Россия, 2014. Режиссер Иван Твердовский. Сценаристы: Иван Твердовский, Мария Бородянская, Дмитрий Ланчихин (по одноименной книге Е. Мурашовой). Актеры: Мария Поезжаева, Филипп Авдеев, Никита Кукушкин, Артём Маркарьян, Ирина Вилкова и др. Драма.

Мальчики + девочки. Россия, 2014. Режиссер Евгений Соколов. Сценарист Евгений Фролов. Актеры: Артём Минин, Влада Лукина, Наталья Меньшова, Андрей Максимов и др. Драма.

Овечка Долли была злая и рано умерла. Россия, 2014. Режиссер Алексей Пиманов. Сценаристы: Галина Сальгарелли, Елена Серова, Алексей Пиманов. Актеры: Данила Шевченко, Юлия Савичева, Виктор Сухоруков и др. Фантастика.

Семицветик. Россия, 2014. Режиссер Елизавета Трусевич. Сценаристы: Дмитрий Полищук, Елизавета Трусевич. Актеры: Светлана Немоляева, Иван Оранский, Анна Потебня и др. Мелодрама.

Учителя. Россия, 2014. Режиссер Вардан Акопян. Сценаристы: Ольга Ларионова, Яна Райская, Юлия Разумовская. Актеры: Марк Богатырёв, Ольга Красько, Ирина Розанова 
и др. Мелодрама.

Я не вернусь. Россия - Эстония - Финляндия, 2014. Режиссер Ильмар Рааг. Сценаристы: Ярослава Пулинович, Олег Газе. Актеры: Полина Пушкарук, Виктория Лобачева, Андрей Астраханцев и др. Драма.

2015

Клинч. Россия, 2015. Режиссер Сергей Пускепалис. Сценаристы: Алексей Слаповский, Сергей Пускепалис. Актеры: Алексей Серебряков, Ася Домская, Агриппина Стеклова и др. Драма.

Призрак. Россия, 2015. Режиссер Александр Войтинский. Сценаристы: Олег Маловичко, Андрей Золотарев. Актеры: Фёдор Бондарчук, Семён Трескунов, Ян Цапник, Игорь Угольников и др. Мистическая комедия.

Работа над ошибками. Россия, 2015. Режиссер Сергей Гиргель. Сценарист Екатерина Андерсон. Актеры: Ольга Бурлакова, Александр Никитин, Вера Полякова, Александр Душечкин и др. Мелодрама.

Сельский учитель. Россия, 2015. Режиссер Дмитрий Сорокин. Сценаристы: Анастасия Экарева, Кира Худолей. Актеры: Артём Семакин, Ирина Таранник, Юлия Кокрятская и др. Драма.

Училка. Россия, 2015. Режиссер Алексей Петрухин. Сценаристы: Екатерина Асмус, Алексей Петрухин. Актеры: Ирина Купченко, Анна Чурина, Андрей Мерзликин, Роза Хайруллина, Алиса Гребенщикова, Ольга Егорова, Алексей Огурцов и др. Драма.

Частное пионерское. Ура, каникулы!!! (Частное пионерское -2). Россия, 2015. Режиссер Александр Карпиловский. Сценаристы: Олег Сироткин, Алла Гусева, Марина Шихалеева, Александр Карпиловский Татьяна Мирошник. Актеры: Семён Трескунов, Егор Клинаев, Анфиса Вистингаузен, Василий Мищенко и др. Комедия.

14+ Россия, 2015. Режиссер и сценарист Андрей Зайцев. Актеры: Глеб Калюжный, Ульяна Васькович, Ольга Озоллапиня, Дмитрий Блохин, Ирина Фролова, Шандор Беркеши, Дмитрий Баринов и др. Мелодрама.

Я - учитель. Россия, 2015. Режиссер Сергей Мокрицкий. Сценарист Алексей Бородачёв.

Актеры: Александр Ковтунец, Юлия Пересильд, Андрей Смоляков и др. Драма.

\section{6}

Два отца и два сына. Россия, 2013-2016. Режиссер: Радда Новикова. Сценаристы: Александр Трофимов, Сергей Сазонов, Василий Смолин, Сергей Лебедев, Алексей Акимов, Станислав Гунько, Александр Завгородний, Александр Касьянов, Сергей Баронов. Актеры: Дмитрий Нагиев, Максим Студеновский, Илья Костюков, Виктория Лукина, Анна Якунина, Галина Петрова, Алика Смехова и др. Комедия.

Любимая учительница. Россия - Украина, 2016. Режиссер Леонид Белозорович. Сценаристы: Мария Бек, Елена Бойко. Актеры: Алина Сергеева, Олег Гаас, Ольга Радчук, Алена Узлюк и др. Драма.

Первокурсница. Россия, 2016. Режиссер Валерия Ивановская. Сценаристы: Евгений Куратов, Вадим Фоминых. Актеры: Анна Тараторкина, Екатерина Симаходская, Алексей Анищенко, Аристарх Венес и др. Мелодрама.

Универ: новая общага. Россия, 2011-2016. Режиссеры: Рустам Мосафир, Константин Смирнов, Максим Зыков, Тимофей Шоталов. Сценаристы: Евгений Соболев, Антон Колбасов, Максим Вахитов, Юлия Галиченко, Илья Полежайкин и др. Актеры: Виталий Гогунский, Арарат Кещян, Станислав Ярушин, Анна Кузина, Настасья Самбурская, Анна Хилькевич и др. Комедия.

Ученик. Россия, 2016. Режиссер Кирилл Серебренников. Сценаристы: Кирилл Серебренников, Мариус фон Майенбург. Актеры: Виктория Исакова, Пётр Скворцов, Александр Горчилин, Юлия Ауг и др. Драма.

Учитель в законе. Схватка. Россия, 2016. Режиссеры: Борис Казаков, Александр Калугин. Сценаристы: Камиль Закиров, Виктор Михеев. Актеры: Юрий Беляев, Игорь Миркурбанов, Александра Флоринская, Юрий Цурило и др. Драма.

Физрук. Россия, 2014-2016. Режиссеры: Сергей Сенцов, Фёдор Стуков, Дмитрий 
Губарев. Сценаристы: Константин Майер, Александр Вялых, Ксения Воронина, Михаил Чистов, Алексей Ляпичев и др. Актеры: Дмитрий Нагиев, Александр Гордон, Полина Гренц, Анастасия Панина и др. Комедия.

Хороший мальчик. Россия, 2016. Режиссер Оксана Карас. Сценаристы: Михаил Местецкий, Оксана Карас, Роман Кантор. Актеры: Семён Трескунов, Анастасия Богатырева, Василий Буткевич, Михаил Ефремов, Иева Андреевайте, Константин Хабенский, Ирина Денисова, Татьяна Догилева, Ирина Пегова и др. Комедия.

\section{7}

Реальные пацаны. Россия, 2010-2017. Режиссер Жанна Кадникова. Сценаристы: Антон Зайцев, Жанна Кадникова, Максим Филипьев, Юрий Овчинников, Денис Шенин. Актеры: Николай Наумов, Зоя Бербер, Антон Богданов, Владимир Селиванов, Станислав Тляшев, Мария Скорницкая, Валентина Мазунина и др. Комедия.

Притяжение. Россия, 2017. Режиссер Фёдор Бондарчук. Сценаристы: Олег Маловичко, Андрей Золотарев. Актеры: Ирина Старшенбаум, Олег Меньшиков, Александр Петров, Никита Кукушкин и др. Фантастика.

Филфак. Россия, 2017. Режиссер Фёдор Стуков. Актеры: Денис Парамонов, Алексей Золотовицкий, Василий Поспелов, Ефим Шифрин, Александра Бортич, Алексей Литвиненко и др. Комедия.

Спасти Пушкина. Россия, 2017. Режиссер Филипп Коршунов. Сценарист Елена Исаева.

Актеры: Константин Крюков, Ирина Крутик, Алексей Лукин и др. Комедия.

Частное пионерское - 3. Россия, 2017. Режиссер Александр Карпиловский. Сценаристы:

Олег Сироткин, Алла Максименко, Александр Карпиловский. Актеры: Семён Трескунов, Егор Клинаев, Анфиса Вистингаузен, Олег Блинов и др. Комедия.

(Составитель фильмографии: Александр Федоров) 